Article

\title{
Towards a Business Model Framework to Increase Collaboration in the Freight Industry
}

\author{
Alix Vargas ${ }^{1, *} \mathbb{C}$, Shushma Patel ${ }^{2, *}$ and Dilip Patel ${ }^{2}$ \\ 1 Transport Systems Catapult, Milton Keynes MK9 1BP, UK \\ 2 School of Engineering, London South Bank University, London SE1 0AA, UK; dilip@lsbu.ac.uk \\ * Correspondence: alix.vargas@ts.catapult.org.uk (A.V.); shushma@lsbu.ac.uk (S.P.); \\ Tel.: +44-7437343123 (A.V.)
}

Received: 8 June 2018; Accepted: 28 September 2018; Published: 9 October 2018

\begin{abstract}
Collaboration in the freight industry has not been widely adopted mainly due to the perceived barriers in competition resulting in a lack of trust among fleet operators. Collaboration in this sector has significant benefits, including the reduction of empty running, operating costs (OPEX) and greenhouse gas emissions (GHG) resulting in greater utilisation of existing logistics assets. A review of the literature to establish the critical aspects of freight collaboration was undertaken, as well as analyses of published case studies and European Union (EU)-funded projects. The critical aspects and barriers identified include: revenue sharing; compliance with competition law; process synchronization; organisational and systems interoperability; different forms of collaboration from a physical and coordination structure perspective; and strategies for collaboration. To facilitate collaboration a freight collaborative business model (FCBM) framework that highlights problematic areas in freight collaboration is proposed to support standardizing collaborative practices in the freight industry. Three published freight industry collaboration business cases were evaluated against the model. The business model framework is intended as a tool to be used to compare different business models and identify the best innovations to help facilitate collaborative practices. The freight collaboration business model was applied to the Freight Share Lab research project in order to demonstrate the concept and investigate whether efficiency can be unlocked through deployment of a dynamic data and asset sharing platform to enable route and load optimization across multiple fleets of freight vehicles, rail freight wagons and containers.
\end{abstract}

Keywords: freight; collaboration; competition; logistics; neutral trustee; business model; fleet operations; decision support systems

\section{Introduction}

The concept of collaboration in the freight industry has been defined as: "A joint initiative of operators within the freight industry to work more closely together in order to reduce the number of Heavy Good Vehicles (HGVs) on the road and therefore decrease greenhouse gas (GHG) emissions. This includes reducing empty running, and identifying routes and journeys where operators can consolidate their loads into a single vehicle trip" [1]. According to the most recent data from the UK Department for Transport (DfT), the percentage of empty running vehicles has increased from $27 \%$ in 2006, to 30\% in 2016 [2]. Therefore, the increasing volume of empty trucks on the road network is beginning to have an impact on traffic congestion, productivity and the environment in the UK. In addition, the loading factor, that is the percentage capacity utilisation of those trucks that were not empty, was only $68 \%$ in 2016 [2]. Collaboration and co-operation between freight carriers is critical to maintain efficient and sustainable transport systems [3]. Strong alliances need to be formed to improve 
operational planning, reduce empty running vehicles, increase capacity utilisation and improve environmental conditions [4].

Collaboration in the supply chain is not new, and it has been used extensively between different supply chain partners [5,6]. Effective collaborations between companies across the supply chain results in reductions in inventories and costs, improvements in speed, service levels, and customer satisfaction [7]. Most of the collaborative initiatives undertaken in the supply chain arena have been between suppliers and manufacturers as well as suppliers and retailers, in areas such as demand planning, sourcing, merchandising, and flow efficiency. However, the freight industry, that represents a vital part of a supply chain, has only limited experience of collaboration in this area, mainly due to its very competitive market and low revenue streams. The review of current literature relating to collaboration in freight activities identifies some techniques to solve specific problems to achieve optimization and benefits for the collaboration partners [8-10]. A recent survey by [11] proposes the classification of these solution techniques in five categories, namely: (1) Framework, which aims to improve the understanding of how collaboration concepts perform. (2) Analytics, which uses mathematical modelling to describe changes in a system. (3) Heuristics, which are used to speed up the process of finding a satisfactory solution for a specific problem. (4) Metaheuristics, which are higher-level solution procedures that provide a sufficiently good solution for an optimization problem, and especially for a problem with incomplete or imperfect information and having a limited computation capacity. (5) Simulation, which is used to show the effects of an action on a system. Each of these solutions solves one collaborative decision, and therefore one problem, in one planning level, strategic, tactical or operational. There is little evidence of research that explores the integration of solutions across all planning levels. This integrated approach would achieve a holistic view of the collaborative process, thus opening up opportunities for new research areas. In addition to this, there is a lack of knowledge of business models that have been successful in the implementation of collaborative networks. There is little evidence of frameworks that seek to highlight different problem areas in freight collaboration. The frameworks proposed in the literature are intended to solve problems relating to strategic partnerships or network configuration $[12,13]$.

The proposed conceptual framework for a freight collaborative business model (FCBM) that will define the critical aspects of collaborative networks, aims to address the gap identified above. The proposed conceptual framework for a FCBM defines the critical aspects of collaborative networks. The benefits of collaboration in the freight industry include: reduction of empty running; reducing operational expenditure (OPEX); and GHG; and achieving greater utilisation from existing logistics assets. In addition to the benefits to fleet operators there are important potential benefits to society: these include reductions in road traffic accidents arising from the need for fewer journeys with greater vehicle utilisation and improvements in air quality due to reduced emissions and congestion. Therefore, the potential for collaborative initiatives to deliver significant benefits in the freight industry is seemingly enormous. The critical aspects that are considered in the FCBM include: revenue sharing, compliance with competition law, process synchronization, organisational and systems interoperability, different forms of collaboration implementation for physical perspectives (horizontal, vertical or lateral), mechanisms of coordination (centralised and/or decentralised) and strategies for collaboration (e.g., backhauling, freight exchangers, consolidation centres, joint optimization). The generic FCBM framework proposed is a novel framework that identifies the critical aspects required to implement successful collaborative and simplified freight-related business models. The framework also clearly defines the relationship between the coordination structure, the collaborative process and the collaborative decisional planning levels. In addition, the FCBM standardizes the key components for collaboration, so it can be used as a tool to compare different business models and identify the best innovative components.

The instantiation of the framework is applied to a case study of collaborating freight operators in the UK and the Freight Share Lab (FSL) project [14]. FSL aims to develop specific solutions to the identified barriers. FSL is a research project, part-funded by Innovate UK, which seeks to investigate 
how it can unlock freight efficiency through deployment of a dynamic data- and asset-sharing platform to enable route and load optimization across multiple fleets of freight vehicles, rail freight wagons and containers.

The paper is structured as follows: Section 2 provides a critical review of the literature in the fields of: collaborative networks, forms of collaboration, collaboration process and technology influencing collaboration. Section 3 presents a conceptual framework for a FCBM based on the literature review and the building blocks needed to model a business in the context of collaboration. In Section 4, the building blocks and the FCBM framework are applied to three freight collaboration published European case studies. In Section 5 the instantiation of the framework is applied to a case study of collaboration among freight operators in the UK, within the Freight Share Lab (FSL) project, which aims to develop specific solutions to the barriers identified. Finally, in Section 6 the main conclusions and suggestions for further work are presented.

\section{Research Context}

\subsection{Collaboration and Collaborative Networks}

Collaboration-based business models not only facilitate reduced costs and improved customer service through shared information/assets and better coordination of collaborative network activities [7], but they also generate synergistic benefits that companies cannot achieve individually. It is important to recognize that the motivation for all parties in the collaborative relationship is to work together to become a "committee of equals" and to find greater value in the collaboration, ensuring its long-term success [15], and supporting coordination to deliver common business objectives [16]. Collaboration is possible when at least two actors share their efforts, data and/or assets to reach a common objective [17]. An increasing number of diverse forms of collaborative networks have emerged due to advances in information and communication technologies, market and societal needs [18]. A collaborative network $(\mathrm{CN})$ is defined as "A network composed of a variety of entities (e.g., organisations, people, machines) that are autonomous, geographically distributed and heterogeneous in terms of their work environment, culture, social capital and objectives, but they collaborate to better achieve common or compatible objectives, generating value together, and whose interactions are supported by computer networks" [19]. Small and medium-sized companies are recognizing the potential of freight collaboration and have started to create collaborative networks to increase narrow profit margins and levels of competitiveness [20].

\subsubsection{Forms of Collaboration}

Two different but interlinked approaches related to the forms of collaboration that exist between the members of collaborative networks have been identified [11,21-23]. The first approach identifies which members engage in the collaboration, and defines the physical structure of the collaboration. The second approach relates to the type of coordination that is established between the members. The two approaches are illustrated in Figure 1 and the order of application is defined. First, it is necessary to identify the partners willing to work together, thus deciding the physical structure of collaboration and then define the form of collaboration between the partners, according to the agreed type of coordination. It also states the obligations and responsibilities of the participants in the collaboration process. The two approaches are:

- Physical structure of collaborative networks: the physical structure of a collaborative network in transport is specific to the sector. Three categories for collaborative schemes in this industry have been proposed: vertical, horizontal and lateral [11,23]:

1. Horizontal collaboration allows two or more unrelated or competing organisations at the same level of the logistics network that cooperate to share their private information or resources, such as transportation. According to [24], horizontal collaboration in transport 
can be categorized in two main streams: (a) Long-distance transportation considers lanes that use full truckloads to be carried from one origin to one destination. The key in this stream is to identify companies that use the same lane but in opposite directions for backhauling trips. This concept is extended in Section 2.2.2. (b) Urban transportation focuses on less-than-truckload requests and short distances. The aim of transport coalitions in this context is to synchronize operations in a way that minimizes the overall number of vehicles needed. Another approach proposed by [25] is the distinction made between two operational approaches: order sharing and capacity sharing.

2. Vertical collaboration allows two or more organisations acting at different levels of the logistics chain, such as a receiver, a shipper, and a carrier, who share their responsibilities, resources and data information, to serve relatively similar end customers of a specific supply chain. Vertical collaboration in transportation predominantly relies on letting service logistics providers decompose transportation routes into multiple tiers. Then, each coalition partner serves one or more dedicated tier or level. This changes the interfaces between tiers, such as urban consolidation centres (UCCs) or satellites, into the main point of contact, where partners' interactions and synchronizations determine the success of efficient deliveries [24].

3. Lateral collaboration enables greater flexibility by combining and sharing capabilities, both vertically and horizontally.

- Coordination structure for collaborative networks: the form of collaboration depends on the type of coordination that is established among the members of the collaborative network. These types of coordination can be: hierarchical coordination, also known as centralised coordination; or non-hierarchical, also known as decentralised [21,22]. For the purposes of this study the terms centralised and decentralised collaboration are used:

1. Centralised collaboration involves making decisions at a higher common level by generating synchronized instructions at lower levels, from a centralised perspective.

2. Decentralised collaboration implies consensus, agreement of objectives, indicators and equality rules between partners. This collaboration is usually achieved through communication and negotiation processes between the partners. Thus, this kind of collaboration is performed from a distributed perspective.

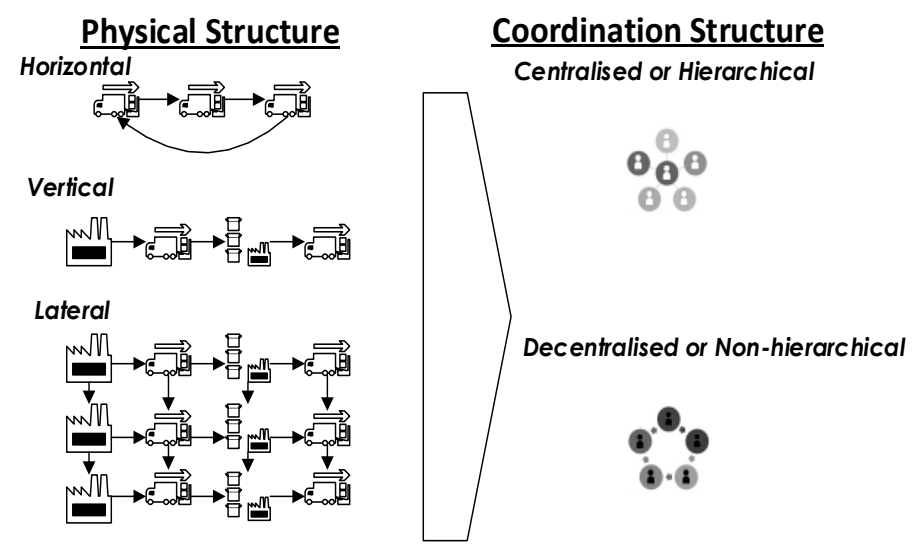

Figure 1. Forms of collaboration from physical and coordination structure perspectives.

\subsubsection{Collaboration Process}

Once the collaboration relationship between the different companies has been agreed, a collaboration process is initiated [21]. The process comprises of five phases: 1. Definition; 2. Exchange Plan; 3. Negotiation and Handling of Exceptions; 4. Execution; and 5. Measurement 
of Results [14]. One of the main drawbacks of the generic process is how to share the benefits in an equitable way to ensure the stability of the collaboration [13]. A solution for this issue is provided by [26] - the definition of a system of compensatory payments, which can be agreed upon in the negotiation and handling of the exceptions phase and can be implemented when the results are evaluated. Other drawbacks in the process include the need for feedback between the parties once the collaboration process has concluded [27], and where the plan must also be revised and modified if necessary [28]. This adapted collaborative process is outlined in Figure 2.

The definition of the type of collaboration between the members of the collaborative network is a joint formal agreement that defines how to proceed. The definition phase must establish the involvement of each partner, the benefits to be obtained, the products or services to collaborate on, the scope of the collaboration, coordination mechanisms, the type of information to be exchanged, the people involved, how to evaluate the results, the compensation system and the mechanisms for resolving conflicts. In addition to the previous definitions, the overall objectives of the collaboration must be defined and prioritised with respect to the individual objectives of each partner [7].

With respect to the exchange plan, it is necessary to define what type of information and assets are going to be shared and how often. Even when the parties involved are implementing this process and are convinced that the synergy will allow them greater joint benefits, it is necessary to define that the information shared and exchanged must be of the highest quality [29]. In defining the conditions of negotiation, it is necessary for the parties to establish an active dialogue that originates in an explicit work model where they also define responsibilities, transparent disclosure of risk factors, incentives and contractual obligations [30].

Once the plans are synchronized and executed, it is necessary to measure the results achieved and, in accordance with these, implement the agreed compensation plan. Finally, it is necessary to jointly evaluate the effectiveness of the plan and propose any improvements. The process then begins again and will be implemented according to the determined planning horizon and is executed in a cyclical manner.

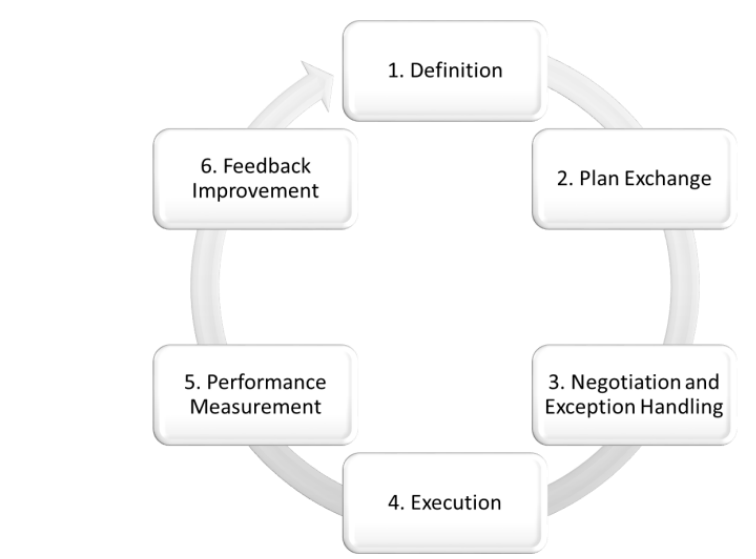

Source: Adapted from [27] with concepts from [13,26,28].

Figure 2. Collaboration process.

The management of each step in the collaboration process must be done in a consistent and coordinated way that guarantees successful collaboration. The form of coordination that the collaborative network decides to follow must align with the culture and mindset of the collaborating partners. In Section 2.1.1, centralised and decentralised collaboration were described as forms of coordinated collaborative networks. In theory, these two forms seem to be exclusive of each other. But in practice an effective way of managing each step in a collaborative process is taking advantage of the benefits of each form of coordination. For instance, the Definition, Plan Exchange and Feedback Improvement phases should be performed in a decentralized way allowing all the partners in the 
collaboration to add value to this process and agree consensually in strategic and tactical decisions. On the other hand, Negotiation and Exception Handling, Execution and Performance Measurement phases need to be led by a central authority that will be impartial and therefore they should be performed in a centralised way.

\subsubsection{Technology Influencing Collaboration}

The developments in telecommunications, information technology, internet, navigation and positioning have created many opportunities to increase collaboration, integration and coordination among the entities operating in logistics networks [4]. Members of logistics collaborative networks that take advantage of affordable information communication technologies have a significant advantage in making use of the opportunities the collaborations may bring. For effective collaborations, the uptake of the technologies will provide the means for members to manage their relationships with logistics partners to utilize synergies (for example, services and excess capacity) that may exist and that would permit increased operational efficiency through reduced operational costs [20]. Information and communication technologies (ICT) including collaborative tools are clearly identified as a major supportive need to add value as a catalyst and enabler for trusted collaborative networks [31]. Information systems and decision support systems within organizations are becoming more important to enable inter-company transactions. Additionally, facilitating decision-making through complex systems that guide decision-makers in assimilating large volumes of information, in a short time to ensure effective decision-making [32].

\subsection{Collaboration in the Freight Industry}

\subsubsection{Stages for Collaboration}

Collaboration between freight companies can take place at different stages and with varying levels of interaction [12]. Collaboration among freight companies normally follows a natural process where companies know each other and learn to identify each partners' mindset and how to work together. The following stages for collaboration have been identified in the freight industry [17]:

- Transactional collaboration: logistics and transportation need consistent administrative practices and document exchanges. The first stage of collaboration consists of coordination and standardization of common administrative practices and exchange techniques, requiring information and communication systems.

- Informational collaboration: this level of collaboration relates to the mutual exchange of information such as shipping forecasts, volumes, locations and timing. At this level, it is noted that confidentiality and the process of competition can hinder collaboration. Information is the key to sharing. Without information sharing, the other levels of collaboration cannot take place [33].

- Decisional collaboration: this focuses on different collaboration opportunities to make planning and management decisions within logistics and transportation. These decisions can be made at different planning levels that are related to the time horizon and level of commitment in terms of the resources that are required. The three levels of planning are: Strategic, Tactical and Operational $[11,24,34]$ :

1. Strategic planning: this involves long term planning, often concerning timescales measured in years. It often results in committing large amounts of resources to service the strategy (including financial, human and capital resources). If an organisation is ready to collaborate, this level functions as the front-end agreement forming the foundation for the entire collaborative process. At this level, two main decisions are taken including the strategic partnership model and the network model. Also, the partners decide whether to enter into a coalition [8,35-37] depending on the perception the partners have about profit and potential partners' characteristics $[9,38,39]$ 
2. Tactical planning: this involves implementing the overall strategy and objectives of the organisation using tactics consistent with the strategy. It often involves shorter time horizons in terms of planning (medium term). It may involve planning horizons in terms of months instead of years. Generally, it will also involve lower levels of resource commitments. At this level, the following decision models are considered: Order Forecasting Model, Shipment Forecasting Model and Carrier Assignment Model. In addition to these and linked directly with the collaboration process, policies to distribute cost and benefits among coalition partners as part of tactical planning should be considered [24]. Therefore, there are two approaches to address the problem: (a) expected benefits are estimated before the partners decide to join the coalition and before deliveries start. In this approach, the information exchange is provided in full for the partners $[9,40,41]$; and (b) it compares the effects of different cost allocations or saving allocations schemes. In this approach the information exchange is limited to supply, demand and cost [38,42-44]

3. Operational planning: this involves day-to-day operations at the ground level. The timescales involved will often be daily or weekly (short term). The resource commitments will be low. Operational plans should be consistent with tactical and strategic plans and should be about implementing the overall strategy. In the freight industry, operational decisions cover the process flow to fulfil the customers' orders on a daily basis. At this level, three main decisions are taken: Scheduling Model, Route Model, and Order Processing Model. However, research in operational planning has focused mainly on solving three problems: (a) collaborative vehicle routing [10,45-47]; (b) crowd-sourced delivery routing [48-51]; and (c) ride sharing [52-55]

Once companies establish trust, the decisional collaboration stage begins. The decisions taken at a strategic level need to follow a decentralised coordination among partners guaranteeing that every partner has an input and are considered equally. Decisions taken at the operational level need to be controlled by a central authority to guarantee the impartiality of the decisions. Therefore, the decisional collaboration is strongly related to the coordination form of collaboration. This relationship is exemplified through a conceptual model proposed in Section 3.

\subsubsection{Strategies for Collaboration}

In freight distribution, the most popular collaborative strategy is sharing capacity. This can take place at the transport level, but also in warehousing, inventory and other operations. These strategies are based on collaborative decision-making and information sharing. They usually take the form of agreements and partnerships among a small number of partners and are usually not formally documented, but are made on an ad hoc basis [12]. Sharing capacity across collaborating carriers is not an easy task, especially if the carriers are spatially spread. The ability to coordinate such collaborative activities becomes a network design problem for the carrier fleet dispatchers because the carriers must coordinate the routing, loading and unloading of the demand over the collaborative network. Another strategy for collaboration, especially for smaller carriers, is the formation of cooperative alliances that are created with the aim of mainly addressing emerging concerns. These include: (1) the increase in requirements by shippers and their spatially spread demand; (2) the influence of both the internet and ICT increasing competition and forming new transportation marketplaces; and (3) an attempt by smaller carriers to achieve the economies of scale exhibited by larger operators, and so collectively enhance their competitiveness. Thus, the challenge for the freight collaborative networks will be to address these issues within a cooperative alliance and to create win-win situations for all the alliance members [20]. The strategies mentioned previously are part of the six strategies suggested by $[1,56,57]$, which are considered in the proposed business model framework: 
1. Route scheduling/planning: this strategy allows for more efficient supply chains and coordinated collaborative networks in a collaborative environment. Organisations involved in logistics need to implement some form of route scheduling and planning as part of their supply chain operations. However, the only way to achieve efficiencies in the supply chain is through collaboration between the different members of the supply chain. For example, vertical collaboration between suppliers and customers may help to optimise order cycles and delivery schedules. Horizontal collaboration for this strategy is also possible. For example, collaboration between carriers to consolidate deliveries for a specific route allows carriers better utilisation of capacity and reduces empty running. However, there is limited evidence of horizontal collaboration taking place, arguably because the business models do not support competition within the collaboration.

2. Backhauling: this strategy of collaboration aims to reduce empty running by ensuring transport returns from a delivery trip with a load. An extension of this may be "forward hauling" where a vehicle is empty whilst 'en route' to pick up a load and therefore the objective of forward hauling is to reduce empty running for any legs of the journey. This can be considered as either a means to fill completely empty loads or to increase loads for vehicles running under capacity. This can be agreed between organisations on an ad-hoc basis or using freight exchange platforms. This kind of collaboration happens between members on the same level of the logistic network and normally implies collaboration between competitors i.e., companies moving goods on the same or very similar routes and/or feeding similar supply chain customers. Therefore, this strategy is related to horizontal collaboration.

3. Freight exchanges: these are online service platforms for logistics providers and other transport companies. These platforms match freight demand and capacity, allowing users to search a database of available freight that needs to be delivered and advertise their available vehicle capacity, and post any transport requirements for tender. Online systems are normally subscription-based with a small charge for advertising and searching. This strategy of collaboration implies different logistics partners sharing information, and is related to lateral collaboration.

4. Consolidation centres: these are logistics facilities situated in relative proximity to the area that they serve, from which consolidated deliveries are carried out. Goods destined for this area are dropped off, and are sorted and consolidated onto suitable goods vehicles for delivery to their final destinations using, in some cases, environmentally friendly cleaner vehicles. These facilities enable companies to group loads with one another and allow goods to be delivered on appropriate vehicles with a high level of load utilisation. This strategy is related to lateral collaboration.

5. Delivery and servicing plans: these plans are designed to reduce the number of goods-vehicle trips generated by premises or wider areas with multiple premises. They are based on the principles of best practice in procurement, ensuring that goods are ordered within a single organisation, and potentially across multiple organisations in partnership, to reduce the total number of trips generated to serve those premises. In general, one organisation acts as the lead supplier-other suppliers channel their products through this lead to consolidate inbound deliveries. For example, this is particularly well suited for deliveries to retail outlets within centrally managed shopping centres, or central business districts with a concentration of offices and public buildings (e.g., local government or educational establishments). This strategy is related to vertical collaboration.

6. Joint optimisation of vehicles and depots: essentially, this strategy involves two (or more) fleets working closely together, sharing a large portion of their joint resources to optimize the service of their current delivery tasks. This style of asset sharing is less evident in practice than backhauling and consolidation centres. However, the barriers to operation are primarily imagination, business models and appropriate technologies to make them work, rather than any capital expense, while the savings in cost and mileage can be quite significant. The idea behind this strategy is to treat the combined resources as if they were those of a single fleet operator, 
so that any vehicle in the combined fleet can serve any of the required deliveries. This strategy is related to horizontal collaboration.

A further step, once different organisations start working together implementing the identified strategies, is developing awareness of the benefits of collaboration by all the collaboration participants. Stronger strategic alliances, like acquisitions or mergers and joint ventures, may then arise as a natural evolution in the collaboration ecosystem. These alliances become market transactions between the parties. In the acquisitions or mergers alliances, one firm takes full control, absorbing another's assets and personnel into a unitary enterprise, requiring no obligation for recurrent cooperation, coordination, or collaboration. In a joint venture, two or more firms create a jointly owned legal organisation that serves a limited purpose for its parents, such as operations, research and development (R\&D) or marketing [58].

\subsubsection{Case Studies of Collaboration in the United Kingdom}

An extensive gathering of real case studies of collaboration in the UK freight industry was carried out by [1]. Table 1 consolidates these case studies and incorporates the classification of (a) physical forms of collaboration, (b) coordination forms of collaboration and (c) categorizes the specific collaboration strategy used.

Analysing the data in Table 1, the following is deduced:

- A total of 15 case studies relating to four industrial sectors have implemented different collaboration strategies: food $(13 \%)$, transport $(20 \%)$, public $(33 \%)$ and retail $(33 \%)$

- Just five of the six strategies defined in Section 2.2.2 have been implemented within the 15 cases presented: Route scheduling/planning (7\%), Freight exchange (7\%), Consolidation centre $(20 \%)$, Joint optimisation of vehicles and depots (27\%) and Delivery and servicing plans (40\%). However, this does not mean that Backhauling is a strategy that is not being used in the freight industry. This strategy is the easiest to implement operationally, needing a miniumum two organisations, while the other four strategies need the formation of a bigger network able to absorb the fixed costs and their operations require additional effort. Consequently, it seems reasonable to suggest that a Backhauling strategy is most likely deployed in the freight industry on an ad-hoc basis and therefore its real implementation by the sector has not been fully represented within the studies. In addition to this, Backhauling might be facilitated by other strategies like Freight exchanges and Joint optimization of vehicles and depots making the use of this strategy less visible, but extracting its benefits in wider strategies.

- The relationship between physical structure and coordination structure for the 15 case studies is presented in Table 2. In terms of coordination structure, centralised collaboration is predominant in $80 \%$ of the cases and decentralised collaboration represents just $20 \%$. In terms of physical structure, vertical collaboration is predominant in $67 \%$ of the cases, followed by horizontal in $20 \%$ and lateral in $13 \%$. Evaluation of the case studies show that horizontal collaboration always seems to be performed using a decentralized approach, while vertical and lateral collaboration adopt a centralized approach.

- All 15 case studies focus on collaboration at the operational level in the decisional collaboration stage. The strategic and tactical decisional collaboration stages are not detailed in the case studies analysed, nor are there details about the collaborative process itself. However, at first glance, it appears these cases follow a unique coordination structure for all the stages of the collaborative process. There seems to be a direct relationship between the different decisional collaboration stages and the collaborative process, which needs further analysis. In Section 2.1.2, it was highlighted that the centralised and decentralised forms of coordination structures should be used, depending on the stages of the collaborative process. It is necessary to emphasise again that the combination of both coordination structures may help to increase the degree of success in a collaborative environment. Section 3 addresses the findings and suggestions raised in this section. 
Table 1. Cases studies of freight industry collaboration in the United Kingdom. Source: Aggregated data from [1] with concepts from [14-17].

\begin{tabular}{|c|c|c|c|c|c|c|c|}
\hline $\begin{array}{l}\text { Case } \\
\text { Study-Company } \\
\text { Name }\end{array}$ & Partner & Sector & $\begin{array}{l}\text { Decisional } \\
\text { Collaboration }\end{array}$ & $\begin{array}{l}\text { Physical } \\
\text { Form of } \\
\text { Collaboration }\end{array}$ & $\begin{array}{l}\text { Coordination } \\
\text { Form of } \\
\text { Collaboration }\end{array}$ & $\begin{array}{l}\text { Strategy of } \\
\text { Collaboration }\end{array}$ & Results in the Collaboration \\
\hline Pall-Ex & $\begin{array}{l}\text { Unidentified } \\
\text { retailer }\end{array}$ & Retail & Operational & Vertical & Centralised & Freight Exchange & $\begin{array}{l}\text { Retailer reported annual savings of } \\
890 \text { tonnes of } \mathrm{CO}_{2} .\end{array}$ \\
\hline Nestle & United Biscuits & Food & Operational & Horizontal & Decentralised & $\begin{array}{l}\text { Joint } \\
\text { Optimisation of } \\
\text { Vehicles and Depots }\end{array}$ & $\begin{array}{l}\text { Annual saving of } 280,000 \mathrm{~km} \text { of road miles, } \\
\text { approximately } 95,000 \mathrm{~L} \text { of diesel and } \\
250 \text { tonnes of } \mathrm{CO}_{2} \text {, as well as generating a } \\
\text { financial saving of } £ 300,000 \text { every year } \\
\text { through working together on back and } \\
\text { forward hauling. }\end{array}$ \\
\hline Kimberley Clark & Manufacturers & Food & Operational & Vertical & Centralised & $\begin{array}{l}\text { Joint } \\
\text { Optimisation of } \\
\text { Vehicles and Depots }\end{array}$ & $\begin{array}{l}\text { Whilst not quantified, the operators reported } \\
\text { savings on } \mathrm{km} \text { and reduced transport costs. }\end{array}$ \\
\hline Sainsbury's & $\begin{array}{l}\text { NFT and } 240 \\
\text { manufacturers }\end{array}$ & Retail & Operational & Vertical & Centralised & $\begin{array}{l}\text { Consolidation } \\
\text { Centre }\end{array}$ & $\begin{array}{l}\text { Reduction of Sainsbury's carbon footprint: } \\
4.6 \text { million } \mathrm{kg} \mathrm{CO} 2 \text {. NFT fleet emissions } \\
\text { reduction: } 1.9 \text { million } \mathrm{kg} \text { of } \mathrm{CO}_{2} \text {. }\end{array}$ \\
\hline Almo & Supplier & Public & Operational & Vertical & Centralised & $\begin{array}{l}\text { Delivery and } \\
\text { Servicing Plans }\end{array}$ & $\begin{array}{l}\text { Deliveries being reduced from the main } \\
\text { supplier by two-thirds. }\end{array}$ \\
\hline $\begin{array}{l}\text { Emirates } \\
\text { Stadium }\end{array}$ & Supplier & Public & Operational & Vertical & Centralised & $\begin{array}{l}\text { Delivery and } \\
\text { Servicing Plans }\end{array}$ & $\begin{array}{l}\text { Reduction in staff's time dealing with } \\
\text { deliveries and also saves the company money } \\
\text { by having fewer invoices to process as well as } \\
\text { reducing vehicle movements. }\end{array}$ \\
\hline DHL & $\begin{array}{l}\text { Retailers in Bath } \\
\text { and Bristol }\end{array}$ & Retail & Operational & Vertical & Centralised & $\begin{array}{l}\text { Consolidation } \\
\text { Centre }\end{array}$ & $\begin{array}{l}\text { Reduction of } 78 \% \text { in vehicle movements, } \\
\text { savings of } 154 \text { tonnes of } \mathrm{CO}_{2} \text { and } 5 \text { tonnes of } \\
\text { NOx and over } 17,900 \text { vehicle trips. }\end{array}$ \\
\hline $\begin{array}{l}\text { Southwark office } \\
\text { DfT }\end{array}$ & Suppliers & Public & Operational & Vertical & Centralised & $\begin{array}{l}\text { Delivery and } \\
\text { Servicing Plans }\end{array}$ & Not available. \\
\hline $\begin{array}{l}\text { Wisbech } \\
\text { Roadways }\end{array}$ & 3 hauliers & Transport & Operational & Horizontal & Decentralised & $\begin{array}{l}\text { Joint } \\
\text { Optimisation of } \\
\text { Vehicles and Depots }\end{array}$ & $\begin{array}{l}\text { Empty running was lower (19\%) and vehicle } \\
\text { fill }(85 \%) \text { was higher than the industry average } \\
\text { and resulted in taking vehicles off the roads. }\end{array}$ \\
\hline $\begin{array}{l}\text { National } \\
\text { confectioner }\end{array}$ & $\begin{array}{l}\text { Customer and } \\
\text { competitor }\end{array}$ & Transport & Operational & Lateral & Centralised & $\begin{array}{l}\text { Route } \\
\text { Scheduling/Planning }\end{array}$ & $\begin{array}{l}\text { Help to utilise the company's assets, and } \\
\text { reduce overall supply chain mileage. }\end{array}$ \\
\hline
\end{tabular}


Table 1. Cont.

\begin{tabular}{|c|c|c|c|c|c|c|c|}
\hline $\begin{array}{l}\text { Case } \\
\text { Study-Company } \\
\text { Name }\end{array}$ & Partner & Sector & $\begin{array}{l}\text { Decisional } \\
\text { Collaboration }\end{array}$ & $\begin{array}{l}\text { Physical } \\
\text { Form of } \\
\text { Collaboration }\end{array}$ & $\begin{array}{l}\text { Coordination } \\
\text { Form of } \\
\text { Collaboration }\end{array}$ & $\begin{array}{l}\text { Strategy of } \\
\text { Collaboration }\end{array}$ & Results in the Collaboration \\
\hline $\begin{array}{l}\text { TNT Olympic } \\
\text { studies }\end{array}$ & Customers & Transport & Operational & Vertical & Centralised & $\begin{array}{l}\text { Delivery and } \\
\text { Servicing Plans }\end{array}$ & Not available. \\
\hline Superdrug & Next & Retail & Operational & Horizontal & Decentralised & $\begin{array}{l}\text { Joint } \\
\text { Optimisation of } \\
\text { Vehicles and Depots }\end{array}$ & $\begin{array}{l}\text { Companies decided to share a vehicle and } \\
\text { loads were consolidated and a vehicle was } \\
\text { taken off the road to the benefit of both } \\
\text { organisations. }\end{array}$ \\
\hline $\begin{array}{l}\text { London } \\
\text { Boroughs } \\
\text { Consolidation } \\
\text { Centre }\end{array}$ & $\begin{array}{l}\text { Camden, Waltham } \\
\text { Forest and Enfield } \\
\text { Councils }\end{array}$ & Public & Operational & Lateral & Centralised & $\begin{array}{l}\text { Consolidation } \\
\text { Centre }\end{array}$ & $\begin{array}{l}41 \% \text { reduction in } \mathrm{CO}_{2} \text { emissions } \\
51 \% \text { reduction in } \mathrm{NOx} \text { emissions, } 61 \% \\
\text { reduction in } \mathrm{PM} \text { ) and over } 70 \% \text { vehicle } \\
\text { capacity utilisation has been achieved. }\end{array}$ \\
\hline Sainsbury's & $\begin{array}{l}\text { Department for } \\
\text { Transport (DfT), } \\
\text { Freight Transport } \\
\text { Association (FTA) } \\
\text { and Noise } \\
\text { Abatement Society } \\
\text { (NAS) }\end{array}$ & Retail & Operational & Vertical & Centralised & $\begin{array}{l}\text { Delivery and } \\
\text { Servicing Plans }\end{array}$ & $\begin{array}{l}\text { Sainsbury's reported improvements in fuel } \\
\text { consumption of } 5.7 \% \text { for night-time operations } \\
\text { compared to daytime equivalents. }\end{array}$ \\
\hline Sutton Council & Suppliers & Public & Operational & Vertical & Centralised & $\begin{array}{l}\text { Delivery and } \\
\text { Servicing Plans }\end{array}$ & $\begin{array}{l}\text { It was expected that it would achieve a carbon } \\
\text { saving of at least } 37,700 \mathrm{~kg} \mathrm{CO}_{2} \text {. }\end{array}$ \\
\hline
\end{tabular}


Table 2. Cases studies of freight industry collaboration in UK.

\begin{tabular}{lccc}
\hline \multirow{2}{*}{ Physical Structure } & \multicolumn{3}{c}{ Coordination Structure } \\
\cline { 2 - 4 } & Centralized & Decentralized & Total \\
\hline Horizontal & & 3 & 3 \\
\hline Vertical & 10 & & 10 \\
\hline Lateral & 2 & 3 & 2 \\
\hline Total & 12 & 35 \\
\hline
\end{tabular}

\subsubsection{European Projects for Freight and Logistics Collaboration}

In recent years, the European Union (EU) has funded many projects with the aim of increasing collaboration in the freight and logistics field. The principal projects include:

- $\mathrm{CO}_{3}$-Collaboration Concepts for Co-modality [59]: the main contribution of the project is the definition of a straightforward methodology of three phases to boost horizontal collaboration between freight actors, using ICT as strategic support for the running of each phase. The phases of this methodology are: Identification, Preparation and Operation. The methodology suggests the existence of a "neutral trustee" facilitator of the collaboration between partners. The neutral trustee entity is an organisation that is responsible for ensuring that the collaborative network is constructed so that a fruitful long term, sustainable relationship between partners can be maintained on a flexible, community basis. The entity has also been referred as "freight traffic controller" (FTC) by [34]. However, the FTC is only in charge of the management of the freight operation among the network partners and the organizations do not intervene in the creation of the collaborative network.

- NexTrust $[3,31,60,61]$ : the NexTrust project focuses on lateral collaboration, and extends the methodology proposed in $\mathrm{CO}_{3}$. Currently, there are more than 40 pilot schemes that are being implemented to prove the effectiveness of the methodology to accelerate collaboration. According to NexTrust the EU permits a neutral trustee to manage compliance within competition law. Partners in a collaboration agreement (possible competitors) could provide commercial data such as: volumes, delivery addresses and product characteristics, etc. to the trustee organisation. This trustee entity can hold and analyse the data given through contract terms. Therefore, compliance with EU competition law is guaranteed. In other words, a trustee organisation is necessary because, without it, it is not possible to transfer commercial data (even of competitors) while looking for efficiencies in the collaborative network. The trusted entity ensures that companies' own legal compliance rules are respected and that confidentiality is in place, thus allowing the exchange of non-commercially sensitive information between the trusted collaborative partners.

- Clusters 2.0 [62]: CLUSTERS 2.0 extends the work undertaken in MODULUSHCA [63] and exploits the "low-hanging fruits" of the physical Internet. CLUSTERS 2.0 considers transport shipments to be open interconnected logistics networks using shared hubs, assets and loading units. The project has three core objectives: to advance the implementation of CargoStream, a shipper driven data collaboration platform; to implement a cluster community system comparable to a port community system among cooperating cluster partners; and to develop a new modular loading unit leading to the development of a standard.

The methodology used by the NexTrust project and the collaboration process described in Section 2.1.2 is directly related, as shown in Figure 3. The proposed collaboration process incorporates more detailed stages than the NexTrust methodology, allowing a better understanding and facilitating the implementation of collaboration in a collaborative environment. In addition, the NextTrust methodology follows a centralised form of collaboration in all its stages. However, by using 
decentralised and centralised collaboration at different stages of the process, further benefits can be achieved.

\begin{tabular}{|l|l|l|}
\hline \multicolumn{2}{|c|}{ Collaborative process } & NexTrust Methodology \\
\hline 1. Definition & & 1. Identification \\
\hline 2. Plan exchange & & 2. Preparation \\
\hline 3. Negotiation and exception handling & & \\
\hline 4. Execution & & 3. Operation \\
\hline 5. Performance mesurement & & \\
\hline 6. Feedback improvement & & \\
\hline
\end{tabular}

Figure 3. Relationship between collaboration process and NexTrust Methodology.

\subsubsection{Barriers for Collaboration and Ways to Overcome Them}

It is clear from the discussion so far, that collaboration in the freight industry is strengthening, because of its potential to add value for shippers, carriers and society. However, it is necessary to understand and identify the reasons why the collaborative networks are not frequently and ordinarily employed in the industry. By defining barriers and limitations for implementing collaboration in the industry, it is possible to identify forms and strategies to overcome them. Table 3 presents the main barriers and limitations from the review of the literature, citing the authors that considered the importance of managing successful collaboration for each barrier and also describes a strategy to overcome each barrier/limitation. Peer reviewed papers, as well as specific freight industry related reports are included in the literature review, to get a better understanding of the challenges facing the freight industry. Two main aspects that are identified as barriers by the majority of authors in the literature review were: (a) legal barriers-competition law, and (b) the lack of a fair system for the allocation of revenues (highlighted in grey in Table 3). These two aspects are specifically addressed in FCBM.

Table 3. Barriers for collaboration in the freight industry and strategies to overcome them.

\begin{tabular}{lll}
\hline Barriers/Limitations for Collaboration & Author & \multicolumn{1}{c}{ Strategies to Overcome Them } \\
\hline $\begin{array}{l}\text { Shipper concerns of having a } \\
\text { different carrier from its usual } \\
\text { contracted carrier to ship its } \\
\text { goods. }\end{array}$ & {$[20] \quad \begin{array}{l}\text { Concerns over branding could be resolved through use of } \\
\text { independent third parties and non-liveried vehicles. } \\
\text { Involving the shipper into the alliance, through agreements } \\
\text { and incentives for the shippers to accept transporting their } \\
\text { goods by different carriers than the usual, showing them the } \\
\text { advantages of collaboration. }\end{array}$} \\
\hline $\begin{array}{l}\text { Purchasing power for small } \\
\text { operators to access information } \\
\text { and communication technologies } \\
\text { (ICT) is limited. }\end{array}$ & [20] & $\begin{array}{l}\text { Create alliances between small operators that allow them to } \\
\text { share the cost of ICT tools and take advantage of scale } \\
\text { economies. }\end{array}$ \\
\hline $\begin{array}{l}\text { Private firms are concerned that } \\
\text { data about their operations } \\
\text { might be used by competitors to } \\
\text { gain business advantage. }\end{array}$ & [64-67] & $\begin{array}{l}\text { Possible interventions to overcome privacy constraints are } \\
\text { anonymisation by filtering of sensitive information and } \\
\text { aggregation of data, thus, only publishing a selection of data } \\
\text { properties and values. Using a trustee figure that is neutral } \\
\text { and impartial where the data is stored and shared in a } \\
\text { confidential environment to optimise routes and schedules } \\
\text { and where each partner just has access to their own data and } \\
\text { the centralised and optimised schedule for day-to-day } \\
\text { operations. }\end{array}$ \\
\hline
\end{tabular}


Table 3. Cont.

\begin{tabular}{|c|c|c|c|}
\hline \multicolumn{2}{|c|}{ Barriers/Limitations for Collaboration } & Author & \multirow{2}{*}{$\begin{array}{l}\text { Strategies to Overcome Them } \\
\text { The European Union (EU) recommends the use of a neutral } \\
\text { trustee, to whom different stakeholders give data to be held } \\
\text { and analysed preventing the transfer of commercial date } \\
\text { such as, volumes, delivery addresses, costs, product } \\
\text { characteristics, etc. }\end{array}$} \\
\hline 4 & $\begin{array}{l}\text { Legal barriers, there are laws that } \\
\text { interfere with the ability to share } \\
\text { data: competition law. }\end{array}$ & {$[1,13,64,66,68]$} & \\
\hline 5 & $\begin{array}{l}\text { Lack of human resources, } \\
\text { especially for small operators. }\end{array}$ & [66] & $\begin{array}{l}\text { By giving to a central entity the authority of decision } \\
\text { making in terms of optimisation and route scheduling for a } \\
\text { group of partners that are collaborating looking for } \\
\text { efficiencies in capacity, cost and societal and environmental } \\
\text { benefits and which have agreed through specific contracts to } \\
\text { follow the central decisions. In this way, there is no need to } \\
\text { increase utilisation of human resources for fleet operators. }\end{array}$ \\
\hline 6 & $\begin{array}{l}\text { Significant coordination is } \\
\text { needed to achieve data and asset } \\
\text { sharing and to accomplish work. }\end{array}$ & [66] & $\begin{array}{l}\text { In a centralised structure collaboration scheme, the central } \\
\text { coordinator is responsible for coordination of the partners in } \\
\text { the collaboration and the partners are committed to follow } \\
\text { central instructions to allow the collaboration scheme to } \\
\text { work. }\end{array}$ \\
\hline 7 & Lack of available accurate data. & {$[1,67,68]$} & $\begin{array}{l}\text { Definition of data structure requirements for collection of } \\
\text { unified and accurate data for collaboration. The } \\
\text { confidentiality of data collection will be defined through } \\
\text { contracts between the partners in the collaboration and the } \\
\text { central trustee authority. }\end{array}$ \\
\hline 8 & Lack of trust and common goals. & {$[1,20]$} & $\begin{array}{l}\text { Use of clear contract agreements, where partners define } \\
\text { confidentiality policies, service levels agreements, penalties } \\
\text { in case of failing, payment conditions, coordination } \\
\text { structure, management of unexpected events and contract } \\
\text { duration. }\end{array}$ \\
\hline 9 & $\begin{array}{l}\text { Lack of a fair allocation } \\
\text { mechanism for collaboration } \\
\text { revenues. }\end{array}$ & {$[1,13,20,69]$} & $\begin{array}{l}\text { Giving different options for revenue sharing to the partners } \\
\text { and showing them the cost benefits of each option will allow } \\
\text { them to choose, during the negotiation phase, which } \\
\text { mechanism will be used for revenue sharing. }\end{array}$ \\
\hline 10 & $\begin{array}{l}\text { A neutral third party is } \\
\text { required to facilitate collaboration. }\end{array}$ & [69] & $\begin{array}{l}\text { A trustee figure is necessary to implement collaboration. } \\
\text { The trustee needs to be a connector between the } \\
\text { collaboration partners. Partners might be reluctant to accept } \\
\text { a third party. But, through contracts between each partner } \\
\text { and the trustee party, it is possible to overcome this. }\end{array}$ \\
\hline 11 & $\begin{array}{l}\text { There are clear regional } \\
\text { imbalances in freight movement, } \\
\text { with high volumes of loads from } \\
\text { one side going to another and less } \\
\text { in reverse. }\end{array}$ & [1] & $\begin{array}{l}\text { Use the practice of triangulation, where a truck is diverted } \\
\text { from its main back route to a third point in order to pick up } \\
\text { a return load, potentially increasing the mileage but } \\
\text { reducing the amount of empty running. }\end{array}$ \\
\hline 12 & $\begin{array}{l}\text { Load compatibility can restrict the } \\
\text { ability for loads to be shared. }\end{array}$ & [1] & $\begin{array}{l}\text { Matching companies moving similar products with similar } \\
\text { handling equipment on similar types of vehicles. }\end{array}$ \\
\hline 13 & $\begin{array}{l}\text { Responsibility for transportation } \\
\text { operations. }\end{array}$ & [64] & $\begin{array}{l}\text { If the collaborations for logistics sharing follow a contract or } \\
\text { a chart where the responsibilities are well defined, these } \\
\text { questions will not constitute an obstacle to sharing. }\end{array}$ \\
\hline 14 & $\begin{array}{l}\text { Unawareness of the benefits of } \\
\text { participating in collaborative } \\
\text { projects. }\end{array}$ & [65] & $\begin{array}{l}\text { Engagement of stakeholders to participate in collaborative } \\
\text { networks is crucial. During the initial engagement, it is } \\
\text { necessary to show to the possible partners the real benefits } \\
\text { of similar collaborative projects and if possible estimated } \\
\text { benefits of the project that they are being asked to } \\
\text { participate in. }\end{array}$ \\
\hline 15 & $\begin{array}{l}\text { High risk of strategic behaviour in } \\
\text { auction collaborative process. }\end{array}$ & [47] & $\begin{array}{l}\text { Effective profit-sharing mechanisms are needed, since these } \\
\text { have the potential to impede strategic behaviour. }\end{array}$ \\
\hline
\end{tabular}

\section{Proposed Freight Collaborative Business Model (FCBM)}

The literature review identifies some of the advances in collaborative freight logistics. However, as outlined above, there are many challenges that need to be addressed at the operational, tactical and 
strategic levels to enable collaboration for better utilization of resources. In this section a collaborative business model that addresses some of the challenges for the freight industry is proposed.

A business model is defined by [70] as: "A conceptual tool that contains a set of elements and their relationships and allows expressing a company's logic of earning money. It is a description of the value a company offers to one or several segments of customers and the architecture of the firm and its network of partners for creating, marketing and delivering this value and relationship capital, in order to generate profitable and sustainable revenue streams". The necessary components or building blocks that a business model should contain have been proposed by [71]. The nine building blocks, described below, are used as the foundation for the proposed business model, with the aim of having a structure and standard to compare the different business models:

1. Value proposition: is an overall view of a company's bundle of products and services that are of value to the customer.

2. Customer segment: is a segment of customers a company wants to offer value to.

3. Customer relationship: describes the link a company establishes between itself and the customer.

4. Distribution channel: is a mechanism for getting in touch with the customer.

5. Key activities: are the most important actions a company must take to operate successfully.

6. Key resources: describe the most important assets (physical, financial, intellectual, or human) required to make a business model work.

7. Key partnership: is a voluntarily initiated cooperative agreement between two or more companies in order to create value for the customer.

8. Revenue model: describes the way a company increases income through a variety of revenue flows.

9. Cost structure: is the representation of income of all the means employed in the business model.

The nine building blocks, described above, only relate to organisations that do not collaborate. However, to develop new collaborative business models, additional building blocks focussed on collaboration and strategies for collaboration are necessary. Figure 4 extends the model proposed by [71] and presents a conceptual framework for FCBM, integrating the concepts defined in Section 2-forms of collaboration, collaboration process, decisional collaboration planning levels and strategies for collaboration.

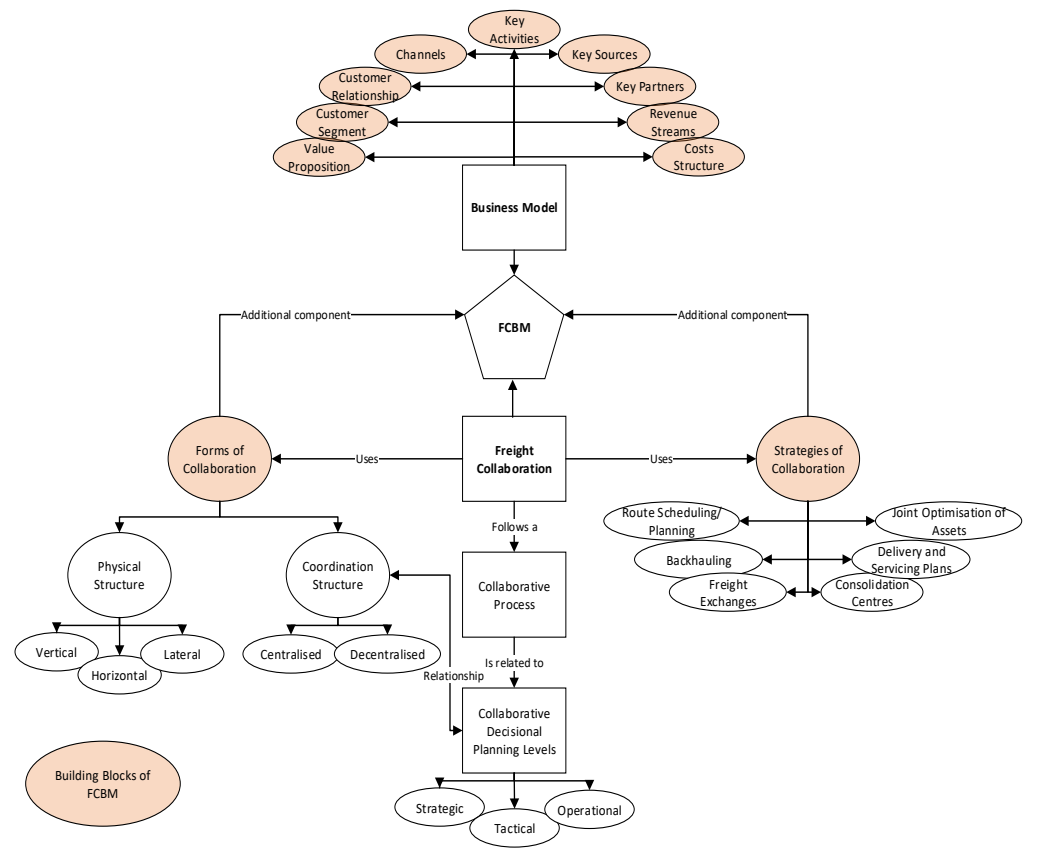

Figure 4. Conceptual framework for freight collaborative business model (FCBM). 
Having defined the FCBM, it is necessary to understand the relationship between the 11 building blocks. Figure 5 represents the relationship between the different building blocks, which can be categorized as five different interfaces or perspectives. The first four interfaces are influenced by the Balance Score Card perspectives suggested by [72] and the last one incorporates the building blocks of collaboration that have been identified previously in this paper in Sections 2.1.1 and 2.2.2:

- The Product Interface: is related to the core of the business and represents the value proposition building block. The other four interfaces (below) are directly interrelated with this building block.

- The Customer Interface: relates to the customer in terms of target customer to offer the value proposition, how it creates a strong relationship with them and the means to deliver the value proposition to them. This interface has three building blocks.

- The Infrastructure Management Interface: relates to how the company efficiently manages infrastructural or logistical tasks, to identify the resources and the type of network enterprise required to support the value proposition. This interface has three building blocks.

- The Financial Aspects Interface: relates to the revenue model and the cost structure that guarantee a business model's sustainability. This interface has two building blocks.

- The Collaboration Interface: relates to the forms of collaboration used among business partners and the strategies implemented by the business that are related to the key activities. This interface has two building blocks.

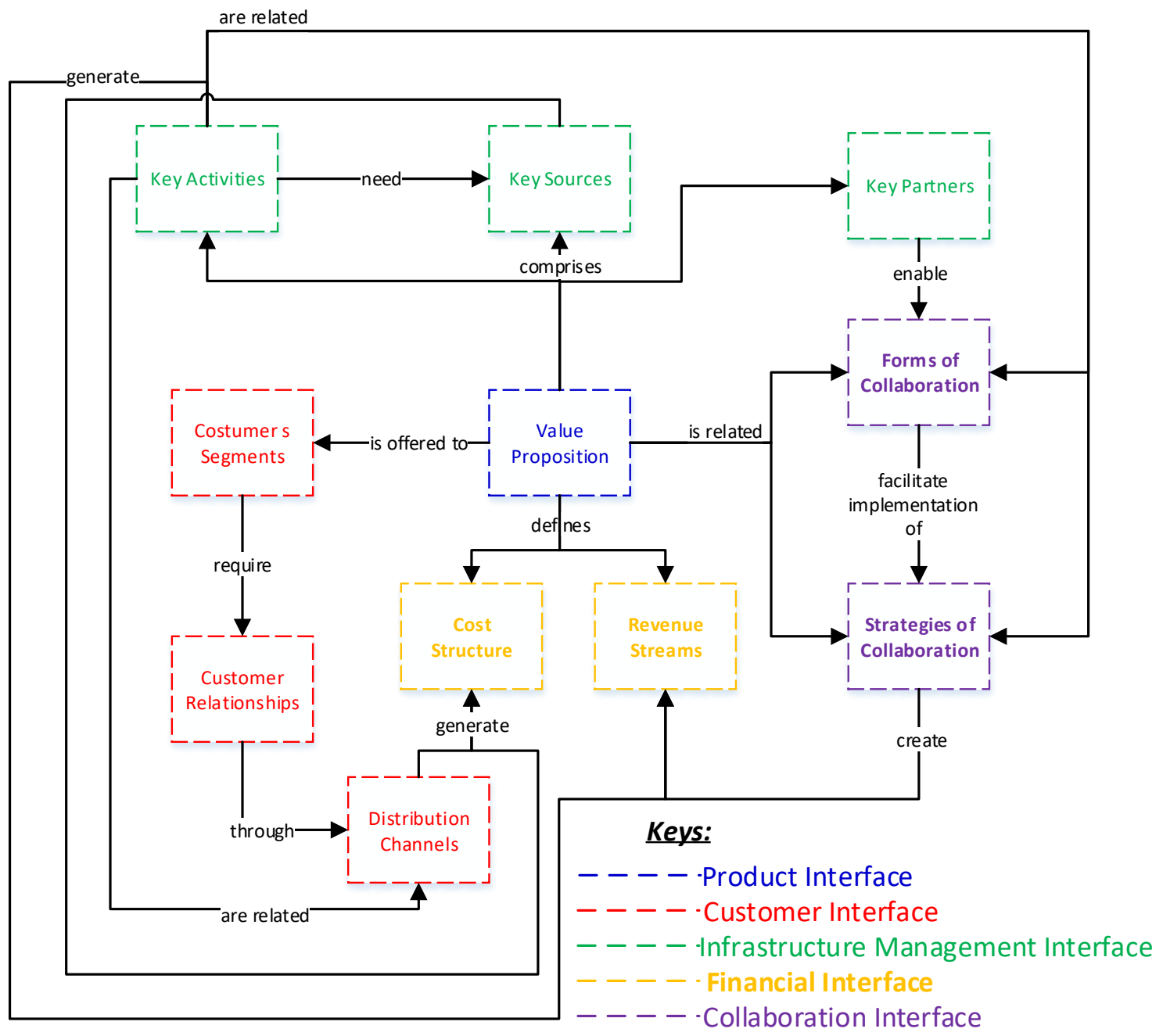

Figure 5. Relationship among building blocks of the FCBM. 
The relationship between the collaborative process, collaborative decisional planning levels and coordination structure (discussed in Section 2) is outlined in Figure 6. Each step of the collaboration process is performed by one of the collaboration structures: Decentralised or Centralised collaboration. It is proposed that the centralized collaboration is led by a neutral trustee, taking into consideration the findings of the European projects mentioned in Section 2.2.4. The Definition/Initiation requires all the partners, including the central authority to agree to collaborate. Plan exchange and Negotiation/Revenue sharing involves defining responsibilities, contracts, joint processes, and mechanisms of revenue sharing among all the partners in the collaboration. The Execution is led by the central authority that informs each partner about the optimized routes and schedules and, each partner follows instructions to complete the assigned task. The Results measure and Revenue sharing execution are performed by the central authority, as per the agreed contract, where the specific mechanism of revenue sharing was selected. Finally, the Feedback is completed among all the partners and it is refined, if necessary, to improve the process and determine if the partners will continue collaborating. Additionally, each step in the collaboration process is associated with one decisional collaborative planning level. At the strategic level, the collaborative partners make two decisions: (1) Initiation of the collaborative network (Step 1) and (2) whether or not to continue with the collaboration after having a Feedback/Improvement session with the collaborative partners (Step 6). At the tactical level, three decisions are made: (1) the Plan exchange where joint processes are defined (Step 2); (2) Negotiation/Revenue sharing mechanism to be used (Step 3); and once the joint operation is executed following the agreements of Step 3, (3) the Results measure and Revenue sharing is also performed (Step 5). At the operational level the decisions made by the central authority are related to the Execution of operations and the optimization of routes and delivery schedules, and only then the carriers follow instructions to accomplish the joint operations plans.
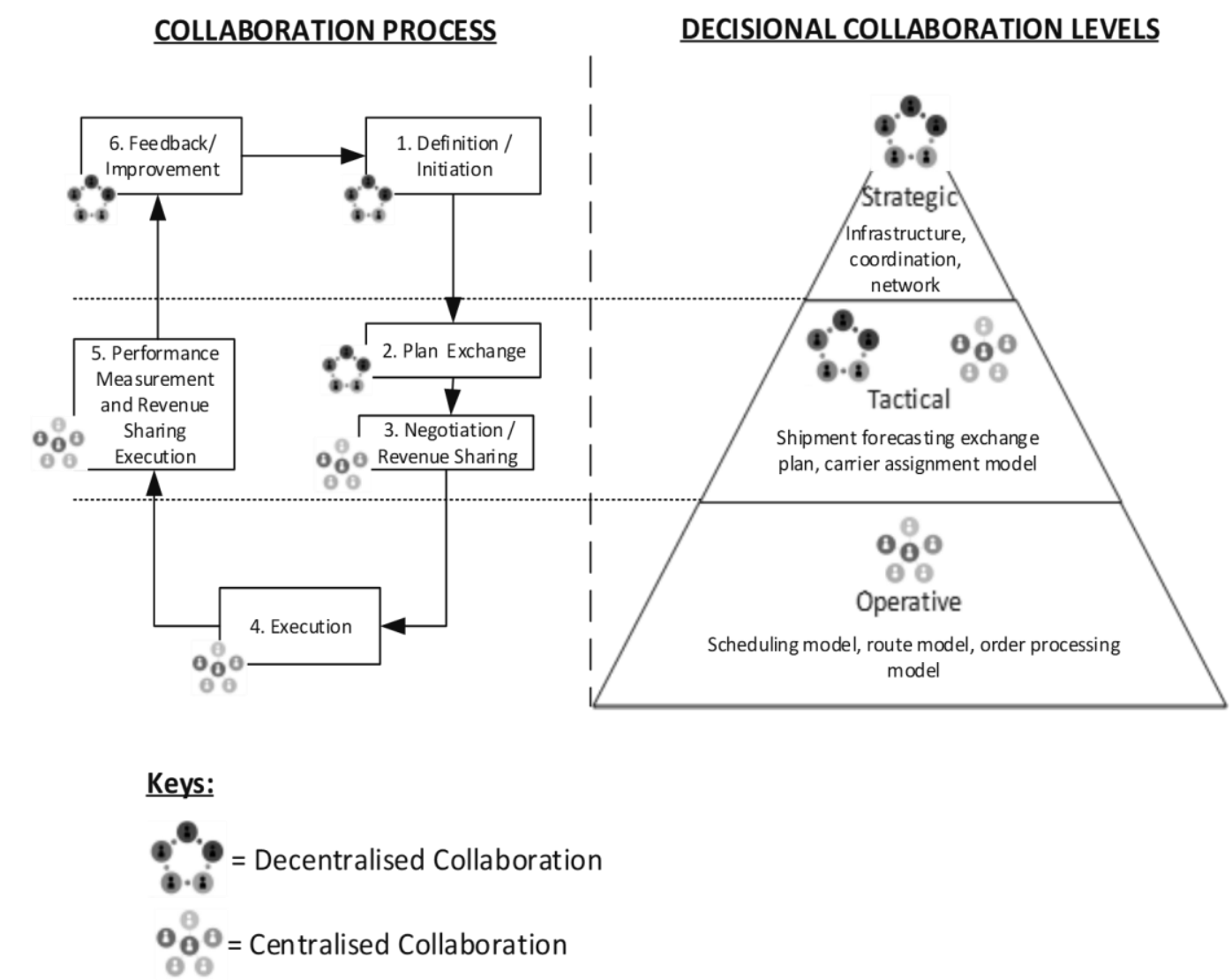

Figure 6. Proposed collaboration process implementation using a combine coordination structure and relationship with decisional collaboration levels. 


\section{Application of FCBM to Published Case Studies}

The FCBM framework and its building blocks were used to analyse the types of business models used in three different published European freight collaboration case studies. The selected business cases are different and, therefore, each building block of each business model has unique characteristics. The three case studies are outlined below:

- Nestlé and United Biscuits-identifying opportunities for reducing empty running through workshops run by Efficient Consumer Response (ECR) UK [73]. In October 2007, United Biscuits transported the first load of Nestle products from Nestlé's York factory to its own distribution centre in Bardon. This venture enabled United Biscuits to transport goods on Nestle's behalf and has resulted in an annual saving of 280,000 km of road miles, approximately 95,000 litres of diesel and 250 tonnes of $\mathrm{CO}_{2}$, as well as generating a financial saving of $£ 300,000$ every year as a result of working together on back and forward hauling. These two competing organisations agreed at a senior management (strategic) level, that their products competed "on the shelf and not in the back of a lorry", and as such worked through the cultural and service barriers that would have previously prevented this level of collaboration [1].

- Mars, United Biscuits, Saupiquet and Wrigley and a trustee logistics service provider (LSP)—logistics collaboration using $\mathrm{CO}_{3}$ methodology [74]. French retailers demand Full TruckLoad (FTL) deliveries from suppliers to their various warehouses throughout France. Vendor Managed Inventory (VMI) makes the suppliers responsible for the inventory replenishment at the warehouses. In 2010, a group of four suppliers, led by Mars, collaborated to fulfil the full truckload delivery requirement and to keep logistics costs under control. The collaboration involved Mars (Pet Foods: Whiskas, Pedigree, Sheba), United Biscuits (Biscuits: Delacre, BN), Saupiquet (Fish products) and Wrigley (candy and gum: Freedent, 5). All four producers have factories in France. From their factories, they transported their products to the shared warehouse in Orléans. The warehouse is operated by a LSP that acts as a neutral trustee and has the function of coordinating shipment, contacting transport companies, and sharing cost savings. From the joint warehouse, collaborative deliveries are made to the various retail warehouses in France. From there, the individual retailers supply their supermarkets. There is evidence of cost savings around $31 \%$ for each company collaborating.

- Returnloads.net-freight exchange platform [75,76]. Returnloads.net was founded in 2000. Initially the site was set up as a noticeboard to help haulage companies around the UK advertise their excess capacity and find return loads for their empty vehicles. In 2006, with the advent of new technologies, Returnloads.net became a fully functioning online freight exchange. This included developing an intelligent load and vehicle matching system, which automatically alerts members to available loads and vehicles that match their requirements. With ongoing development, Returnloads.net has continued to grow-with over 90,000 available haulage loads posted on the platform every month. It now has over 1500 users from across the UK including owner-drivers, freight forwarders and several of the country's largest haulage firms. In 2016 loads totalling over 16.5 million miles were covered on the platform resulting in a potential saving of 25,514 tonnes of $\mathrm{CO}_{2}$.

The FCBM was applied to the case studies. Each building block of each case study was assessed. The evaluation criteria are outlined below in Figure 7. The building blocks were assessed against each assessment factor on a scale of 1 (low) to 10 (high). This assessment system is based on [70]. 
BUILDING BLOCKS $\quad$ ASSESMENT VALUE $\quad$ ASSESMENT FACTOR

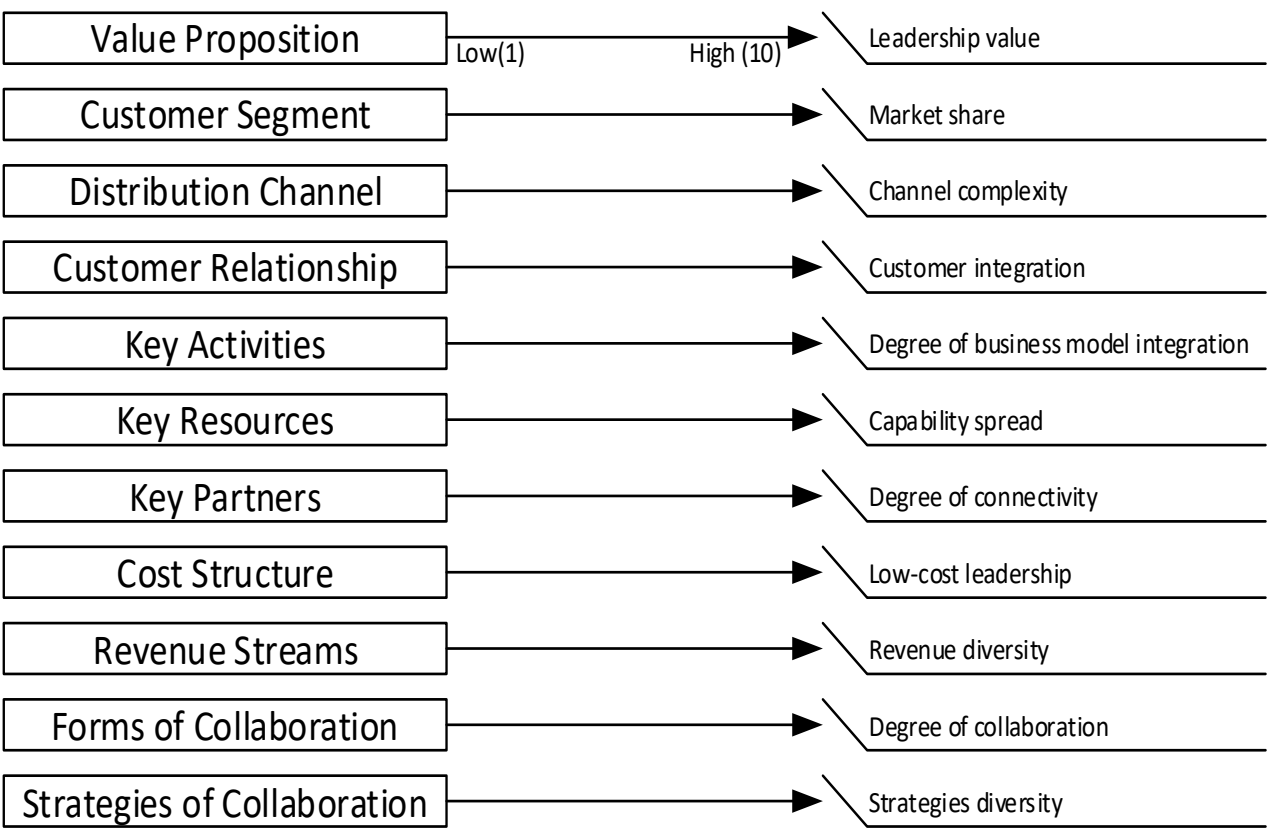

Figure 7. Assessment factor categorization per building block. Source: Adapt from [70].

Table 4 summarises the analyses of business model building blocks for each of the three business cases. The assessment identifies which business case is perceived to have the strongest business model when compared with each other. Each building block was assessed according to the assessment factors defined in Figure 7. Table 4 assessment is colour-coded. Black characterises the highest value of " 10 ", grey represents the medium value of " 5 ", and white represents the lowest value of " 1 " for the three business cases evaluated. The categorization helps to configure new business models by taking the highest building block values into account. The categorization does not mean that the lowest building block value should be dismissed. In fact, the lowest building block value might be the only and correct building block for its specific business case; however, compared with a different set of business cases it might be the highest building block value.

Table 4. Business model building blocks categorization for freight industry collaboration business cases.

\begin{tabular}{|c|c|c|c|}
\hline \multirow[b]{2}{*}{$\begin{array}{l}\text { Business Model } \\
\text { Component }\end{array}$} & \multicolumn{3}{|c|}{ Business Cases } \\
\hline & $\begin{array}{c}\text { Nestle and United } \\
\text { Biscuits }\end{array}$ & $\begin{array}{l}\text { Mars, United Biscuits, } \\
\text { Saupiquet and Wrigley }\end{array}$ & Returnloads \\
\hline Value Proposition & $\begin{array}{l}\text { Collaboration between } \\
\text { competitors to reduce } \\
\text { empty running }\end{array}$ & $\begin{array}{l}\text { Collaboration using a } \\
\text { neutral trustee (LSP) to } \\
\text { comply with customer } \\
\text { requirements }\end{array}$ & Freight Exchange service \\
\hline Customer segment & $\begin{array}{l}\text { Retailers and their } \\
\text { distribution centres in } \\
\text { Midlands }\end{array}$ & $\begin{array}{l}\text { Distribution centres in } \\
\text { France }\end{array}$ & $\begin{array}{l}\text { Fleets and shippers in } \\
\text { UK }\end{array}$ \\
\hline $\begin{array}{l}\text { Customer } \\
\text { relationship }\end{array}$ & $\begin{array}{l}\text {-Customers were } \\
\text { consulted to agree in the } \\
\text { brand identity in case } \\
\text { products of different } \\
\text { brands need to be } \\
\text { transported in the } \\
\text { competitors trucks. }\end{array}$ & $\begin{array}{l}\text { _Close relationship to be } \\
\text { able to comply with the } \\
\text { mandatory customer } \\
\text { request of full truckload } \\
\text { deliveries to their } \\
\text { distribution centres }\end{array}$ & $\begin{array}{l}\text { Close relationship to } \\
\text { inform the functionality } \\
\text { of the platform, } \\
\text { including freight alerts to } \\
\text { suitable members aiming } \\
\text { personalization }\end{array}$ \\
\hline
\end{tabular}


Table 4. Cont.

\begin{tabular}{|c|c|c|c|}
\hline \multirow[b]{2}{*}{$\begin{array}{l}\text { Business Model } \\
\text { Component }\end{array}$} & \multicolumn{3}{|c|}{ Business Cases } \\
\hline & $\begin{array}{l}\text { Nestle and United } \\
\text { Biscuits }\end{array}$ & $\begin{array}{l}\text { Mars, United Biscuits, } \\
\text { Saupiquet and Wrigley }\end{array}$ & Returnloads \\
\hline Channels & Retail & $\begin{array}{l}\text { Retai } \\
\mathrm{CO}_{3} \text { Network }\end{array}$ & $\begin{array}{l}\text { Digital platform that } \\
\text { connects offer and } \\
\text { demand }\end{array}$ \\
\hline Key activities & $\begin{array}{l}\text { _Produce summary of } \\
\text { lanes and volumes } \\
\text { _Identify potential } \\
\text { collaborative lanes } \\
\text { _Agree rates on lane by } \\
\text { lane basis } \\
\text { _Agree KPI's and review } \\
\text { mechanism } \\
\text { _Run Pilot } \\
\text { _Review Pilot } \\
\text { _Roll Out }\end{array}$ & $\begin{array}{l}\text { _Legal and formal } \\
\text { contract between } \\
\text { partners } \\
\text { _Trustee figure } \\
\text { responsible for } \\
\text { coordination of } \\
\text { shipments and gain } \\
\text { sharing allocation } \\
\text { _Negotiation and } \\
\text { selection between } \\
\text { partners of mechanism } \\
\text { of saving cost sharing } \\
\text { (cost per shipment, } \\
\text { Shapley value and equal } \\
\text { profit margins) }\end{array}$ & $\begin{array}{l}\text { _A carrier places a load } \\
\text { to be subcontracted out } \\
\text { or a shipper posts a load } \\
\text { that needs delivering } \\
\text { _Each load will be } \\
\text { matched to suitable } \\
\text { members and freight } \\
\text { alerts will be sent out to } \\
\text { them via emai } \\
\text { _Fleets and shippers } \\
\text { negotiate rates and } \\
\text { payment conditions }\end{array}$ \\
\hline Key resources & $\begin{array}{l}\text { Shared fleet assets and } \\
\text { human assets }\end{array}$ & $\begin{array}{l}\text { Shared shippers assets, } \\
\text { human assets and } \\
\text { processes definition }\end{array}$ & $\begin{array}{l}\text { Digital platform, human } \\
\text { assets and processes } \\
\text { definition }\end{array}$ \\
\hline Key partners & Competitors & $\begin{array}{l}\text { Complementary } \\
\text { products partners and } \\
\text { trustee }\end{array}$ & $\begin{array}{l}\text { No partners involved for } \\
\text { collaboration }\end{array}$ \\
\hline Revenue Streams & $\begin{array}{l}\text { _Non saving cost sharing } \\
\text { nor subscription fee. } \\
\text { _There is evidence of cost } \\
\text { savings for both partners } \\
\text { and reduction of emissions }\end{array}$ & $\begin{array}{l}\text { For trustee: Partners } \\
\text { pay to the trustee/LPS } \\
\text { per: (1) The coordination } \\
\text { of the shipments and the } \\
\text { communication with } \\
\text { transport companies. (2) } \\
\text { The gain sharing and fair } \\
\text { cost allocation } \\
\text { _For shippers: cost } \\
\text { savings }\end{array}$ & $\begin{array}{l}\text { Annual fee subscription } \\
\text { plan }\end{array}$ \\
\hline Cost structure & $\begin{array}{l}\text { _Time cost for attending to } \\
\text { workshops } \\
\text { _Operational cost }\end{array}$ & $\begin{array}{l}\text { _Time cost for attending } \\
\text { to meetings } \\
\text { _Operational cost }\end{array}$ & $\begin{array}{l}\text { _Operational cost } \\
\text { _Digital platform } \\
\text { maintenance } \\
\text { _Advertising }\end{array}$ \\
\hline $\begin{array}{l}\text { Forms of } \\
\text { collaboration }\end{array}$ & $\begin{array}{l}\text { _Horizonta } \\
\text { _Decentralised }\end{array}$ & $\begin{array}{l}\text { _Horizonta } \\
\text { _Centralised/Decentralise }\end{array}$ & $\begin{array}{l}\text { _Latera } \\
\text { _Centralised }\end{array}$ \\
\hline Strategies & $\begin{array}{l}\text { Joint optimization of } \\
\text { assets }\end{array}$ & $\begin{array}{l}\text { _Route } \\
\text { scheduling/planning } \\
\text { Joint optimization of } \\
\text { assets }\end{array}$ & _Freight Exchange \\
\hline & Assessment Value Keys & & \\
\hline & Highest & & \\
\hline & Medium $\quad=$ & & \\
\hline & Lowest & & \\
\hline
\end{tabular}

Figure 8 compares the three business models analysed in the freight industry. The comparison shows that the business model perceived to be the strongest is the Mars, United Biscuits, Saupiquet and Wrigley business model, with seven out of 11 factors with the highest values and four in the medium range of values. The next strongest business model is Return Loads with three out of 11 factors with the highest values and three in the middle range. The least strong business model is Nestle and United Biscuits with one factor in the highest value range and three in the medium value range. 


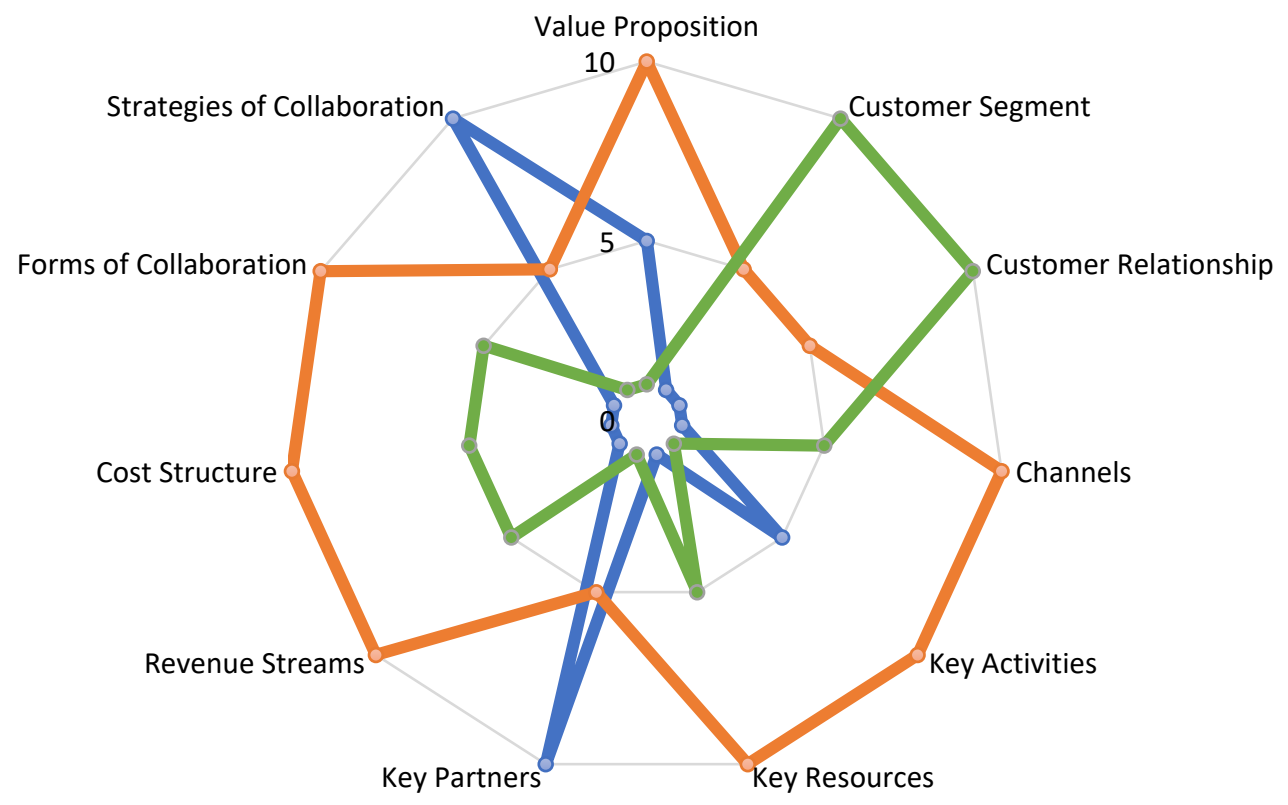

$\longrightarrow$ Nestle and United Biscuits $\longrightarrow$ Mars, United Biscuits, Saupiquet and Wrigley $\longrightarrow$ Returnloads

Figure 8. Collaborative business model comparison in the freight industry.

The FCBM can be used as a tool to compare different business models, through a systematic approach that evaluates their components or building blocks. This approach opens the possibilities for a new and improved generation of business models that holistically integrate the most innovative building blocks that cover specific issues of freight collaboration.

\section{FCBM Instantiation}

Based on the findings of the previous sections, this section illustrates how the FCBM was applied to the "Freight Share Lab" (FSL) project. FSL is a research project, part-funded by Innovate UK, which investigates whether freight efficiency can be unlocked through deployment of a dynamic data- and asset-sharing platform to enable route and load optimization across multiple fleets of freight vehicles and rail freight wagons and containers. Computer modelling, carried out by the World Business Council for Sustainable Development (WBCSD), has indicated efficiency improvements of over 20\% could be possible if freight shippers and carriers were able to share their vehicles and freight [56]. The FSL research project has a lifecycle of 30 months seeking to investigate if this potential can be realised in real-world conditions. Decision support systems and optimization software for routing and scheduling can lead to improved operational efficiency. However, as this tends to be implemented independently in each organisation, there are limitations to what can be achieved. FSL explores whether it is possible to build out from the single-customer model and develop a platform for inter-company collaboration. Therefore, FSL will encompass the optimisation of shared assets across companies applying sophisticated routing and scheduling to multiple companies' assets as if they operate as a single entity. Figure 9 represents the concept of FSL compared to single road vehicle/company optimization and freight-exchange platforms. The FSL platform aims to combine the benefits of single fleet optimization and the use of freight-exchange platforms. The FSL platform will collectively optimise routes for several fleets, including sharing opportunities as part of the optimization process. The four main high-level steps of the envisaged operational process are: 
1. The fleet provides data about a specific job and the agreed price to the platform. This data is stored into the FSL database and treated confidentially. Therefore, the different fleets do not have visibility of the data provided by other fleets.

2. The FSL platform knows each fleets' sharing rules and arrangements.

3. The FSL platform jointly optimizes the fleets, optimizing routes and sharing opportunities by taking into account the various jobs entered by the fleets.

4. The platform provides the results, including the cheapest option per job, a route for each fleet, and indicates any sharing opportunities.

(a)

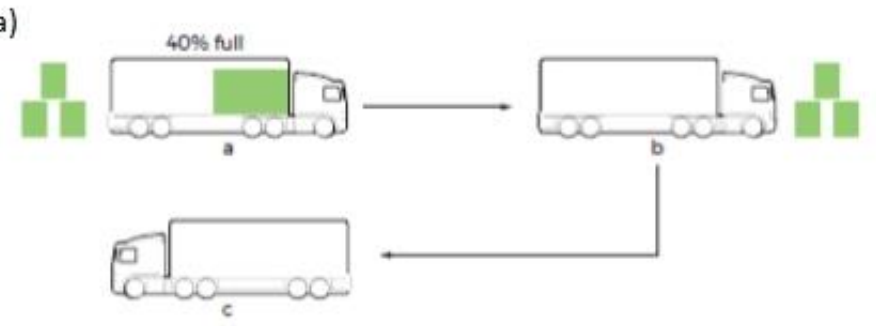

(b)
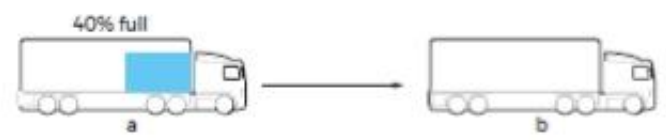

(c)
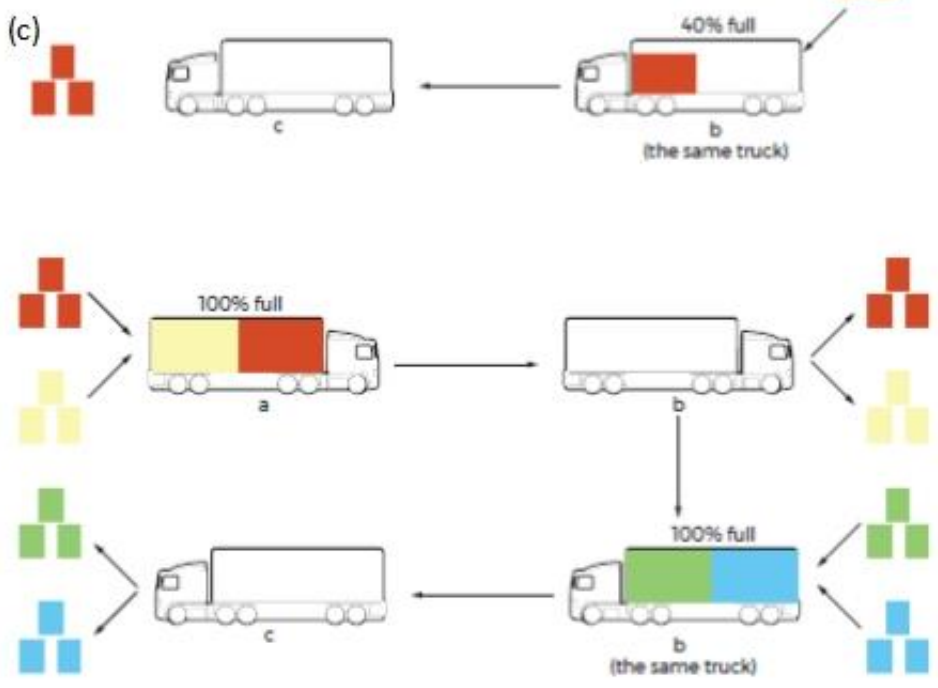

Source: FSL

Figure 9. Concept model of FSL. (a) Single fleet: one vehicle, one company's delivery. (b) Freight exchange: one vehicle, two companies' deliveries. (c) FSL platform: one vehicle, several companies' deliveries.

It is important at this stage to clarify the economic benefits of using the platform. Figure 10 shows an example for a specific job that is submitted to the platform:

- The Operational View shows the simplified process of choosing the cheapest option. The data in the database has been previously provided by the fleets in terms of total cost per kilometre or rate. The estimated gross cost is calculated by applying the agreed profit percentage to the net cost or rate. In this case, the cheapest option is selected for a different fleet than the originally contracted fleet. 
- The Economic View shows the savings gained by each of the coalition partners using the FSL platform. Each of the coalition partners take their share of profit immediately after the customer fulfils payment. For this, it is proposed the savings are invested in a low-risk financial system that generates interest over a specific period. The financial system has been called FSL Bank for hypothetical purposes. The savings-sharing mechanism proposed is based on game theory and equally incentivizes two different behaviours, namely: (a) submitting contracts/jobs to the platform; and (b) performing the transport. The first behaviour incentivizes fleets to submit as many jobs as they have because they will still win their own profit if another fleet is chosen to perform the transport. The second behavior incentivizes fleets to keep costs low in order to be chosen by the platform. This approach builds competitiveness in the network between the fleets and offers economic benefits that will not be achievable by acting in isolation. Fleets that are part of the network, but do not actively participate, will not receive any benefits. The details of this saving-sharing mechanism are not discussed further in this publication. At the time of writing this mechanism was being evaluated by the stakeholders.

- The Benefits View summarizes the economic benefits for each of the fleets involved in the platform.

As previously described, the FSL platform seeks to guarantee benefits to the fleets that join the network. By joining the network, fleets will always win or at least will not lose anything. If the platform identifies a fleet that can do the job more cheaply, the contracted fleet will always receive its share of the profit. If the platform does not find the cheapest option, the original fleet will perform the job, anyway. In the latter case, there are no savings to share and, therefore, there is no extra benefit for the fleet performing the job.

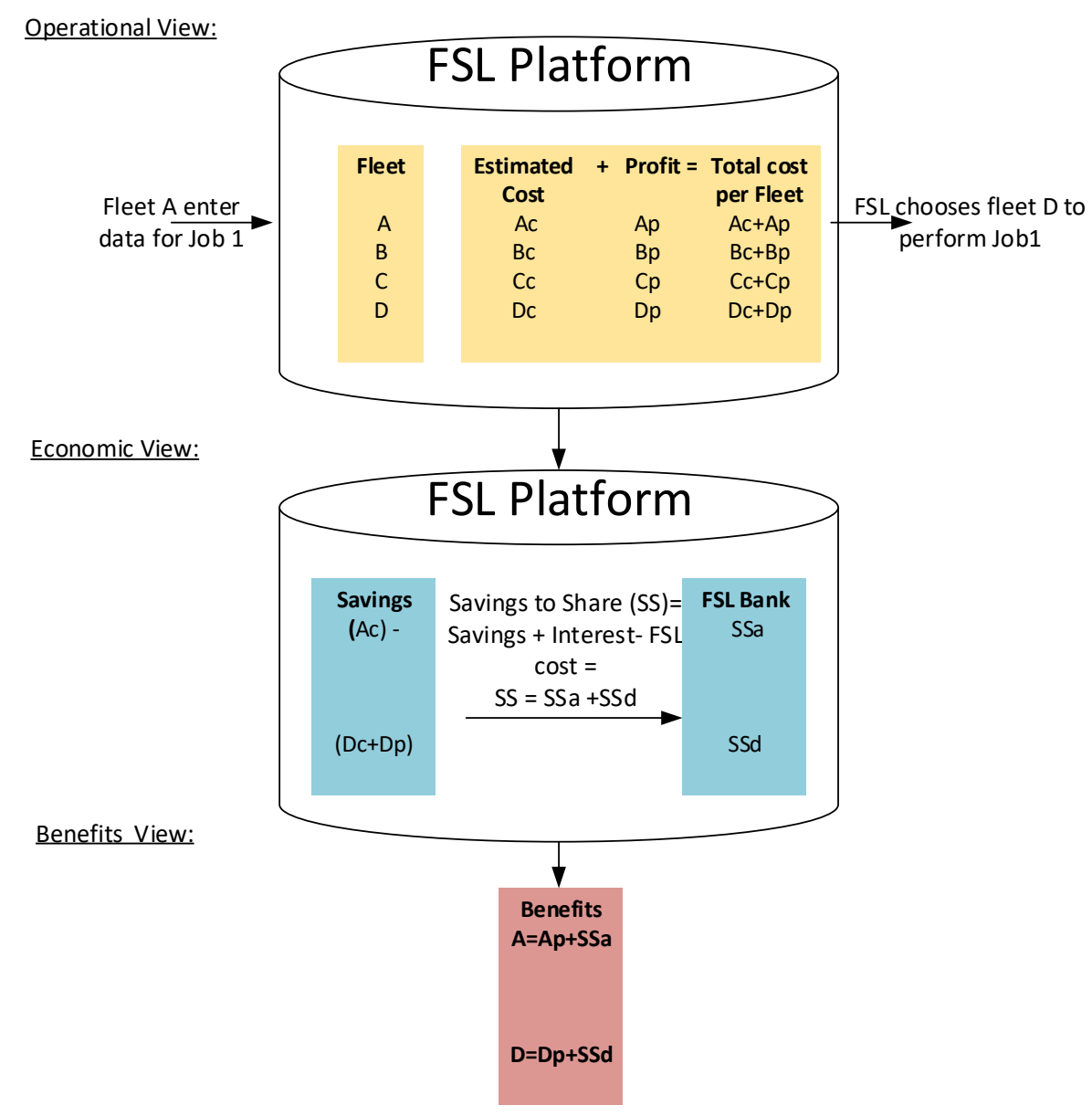

Figure 10. Schematic representation of operational, economic and benefits view for the Freight Share Lab (FSL) platform. 
The idea behind the FSL platform is to increase competitiveness and efficiency among fleets that are part of the network by creating a collaborative ecosystem, whereby the members always win. The goal of FSL is to reallocate jobs between the collaborating members where the total fulfilment costs are lower than the sum of non-collaborating fleets individual fulfilment costs. The cost savings achieved reflect the benefits of acting in coalition rather than independently. These joint benefits are then shared by the members in such a way that all active fleets in the FSL platform will improve their profitability.

FSL targets four main customer segments: small as well as large fleet operators, shippers and aggregators. All customers will benefit from having a platform that can provide centralized logistics optimization to help simplify their operations. Platform features, which aim to improve customer efficiency, include direct online platform payments as well as tracking of shipments, compliance, driver training with feedback and easy reporting. Hypothetically, small operators have the most to gain from using FSL because they will have access to more jobs, their margins will improve with increased utilization rates and it gives SMEs the opportunity for new business development and marketing. Similarly, large fleets gain access to additional jobs and the opportunity of covering areas where there is low offer by SMEs that have the capabilities to perform those jobs. However, the true added value is the ability to reduce their costs (e.g., reducing fuel, trip times and overheads) and $\mathrm{CO}_{2}$ emissions by an average of $20 \%$. To add value to all stakeholders along the distribution supply chain, the platform aims to include current freight and logistics aggregators who benefit from faster deliveries, broader geographic coverage, and economies of scale.

The conceptual collaborative freight operation model for FSL is presented in Figure 10. A single fleet (one vehicle, one company's delivery) represents the status of most fleet operations and only optimizes the route taken by a single fleet. Freight exchange (one vehicle, two companies' deliveries) is the service provided by several companies. The existing offerings find sharing opportunities between two fleets on the basis of "pre-optimized" (or simply pre-planned) routes. FSL platform (one vehicle, several companies' deliveries) provides optimization of all assets and routes.

The instantiation of the FCBM for the FSL project is proposed in Table 5 and takes into consideration the analysis of the case studies performed in the UK and European projects (Sections 2.2.3 and 2.2.4); the strategies to overcome the barriers identified in Section 2.2.5; and the best practices of business model building blocks acknowledged in Section 3 .

Table 5. FCBM building blocks instantiation for FSL.

\begin{tabular}{ll}
\hline Business Model Building Blocks & \multicolumn{1}{c}{ Description } \\
\hline Value Proposition & $\begin{array}{l}\text { The collaboration between competitors and non-competitors to } \\
\text { reduce empty running by using a neutral trustee based on an online } \\
\text { platform to initiate the collaboration process and, to arrange } \\
\text { scheduling and routing among partners and cost sharing. }\end{array}$ \\
\hline Customer Segment & $\begin{array}{l}\text { Fleet operators (small and large size), shippers and aggregators in } \\
\text { the UK }\end{array}$ \\
\hline Customer Relationship & $\begin{array}{l}\text { - External customers and their representatives are involved in the } \\
\text { advisory group to understand expectations. } \\
\text { - Internal customers' needs are taken into account through } \\
\text { interviews and workshops. }\end{array}$ \\
\hline \hline Channels & $\begin{array}{l}\text { - Face-to-face workshops for initiation. } \\
\text { - Digital platform for operation. } \\
\text { - Regular meetings between partners and trustee to build trust and } \\
\text { incentivise collaboration. } \\
\text { - Communications through advisory group channels and DVV } \\
\text { Media International (DVV) publications and events. }\end{array}$ \\
\hline
\end{tabular}


Table 5. Cont.

\begin{tabular}{|c|c|}
\hline Business Model Building Blocks & Description \\
\hline Key Activities ${ }^{1}$ & $\begin{array}{l}\text { - Identification of clusters among participants. } \\
\text { - Legal and formal contract between partners. } \\
\text { - Neutral trustee responsible for legal requirements for initiation of } \\
\text { collaborations. } \\
\text { - Negotiation among partners about workflow process and sharing } \\
\text { revenue method that is defined in the contract agreement. } \\
\text { - Operation management in terms of scheduling and routing done } \\
\text { by the neutral trustee. } \\
\text { - Neutral trustee to share the cost savings and revenues among } \\
\text { partners following contract agreement. } \\
\text { - Periodic review of collaboration performance. }\end{array}$ \\
\hline Key Resources & $\begin{array}{l}\text { - Shared assets (fleets, warehouses, equipment). } \\
\text { - Human assets. } \\
\text { - Digital platform with optimization algorithms. } \\
\text { - Processes definition. }\end{array}$ \\
\hline Key Partners & $\begin{array}{l}\text { - TrackM8 acting as a neutral trustee. } \\
\text { - Transport Systems Catapult. } \\
\text { - Herriot Watt University. } \\
\text { - DVV Media International. } \\
\text { - World Business Council for Sustainable Development (WBCSD). }\end{array}$ \\
\hline Revenue Streams & $\begin{array}{l}\text { - Non-subscription fee. The FSL platform will use the savings and } \\
\text { interest generated to pay for the operation of the platform and } \\
\text { therefore the services of the neutral trustee. } \\
\text { - Neutral trustee to share the cost savings among partners } \\
\text { depending on the selected method based on game theory. }\end{array}$ \\
\hline Cost Structure & $\begin{array}{l}\text { - Operational cost (including marketing and sales). } \\
\text { - Labour cost. } \\
\text { - Digital platform maintenance. }\end{array}$ \\
\hline Forms of Collaboration & $\begin{array}{l}\text { - Centralised and decentralised depending on the stage of the } \\
\text { collaborative process. } \\
\text { - Multilateral. }\end{array}$ \\
\hline Strategies of Collaboration & $\begin{array}{l}\text { - Route scheduling/Planning. } \\
\text { - Backhauling. } \\
\text { - Freight exchange. } \\
\text { - Consolidation centres. } \\
\text { - Delivery and servicing plans. } \\
\text { - Joint optimisation of assets. }\end{array}$ \\
\hline
\end{tabular}

${ }^{1}$ The detail for the key activities is reflected in the workflows proposed in Figures 10-13.

The "Key Activities" building block addresses most of the barriers identified. This suggests that the focus of the proposed business model framework is on explaining how the key activities are performed and how other building blocks feed into it and vice versa. To investigate this, an initial approach to define the relationship among the 11 building blocks for the FCBM was proposed (Figure 5), in Section 3. In addition, the key activities are strongly related to the stages of the collaborative process and the coordination structure proposed in Figure 6. The latter is also a part of the "Forms of Collaboration" building block that is clearly related to the key activities building block. In summary, the initial findings outlined in Figures 5 and 6, can be extended by defining workflows that describe the key activities building block in more detail:

- Figure 11, reflects Stages 1, 2 and 3 of the collaboration.

- Figure 12, represents Stage 4 of the collaboration process. 
- Figure 13, describes the importance of managing unexpected events during the collaboration process. Some research in this area has been done specifically in the management of unexpected events in hierarchical production planning [32,77].

- Figure 14, explains Stages 5 and 6 of the collaboration process.

The proposed workflows identify the main partners involved, the resources needed, the forms of collaboration used, the distribution channels utilized, and the revenue streams identified for validating the proposed relationship among building blocks.

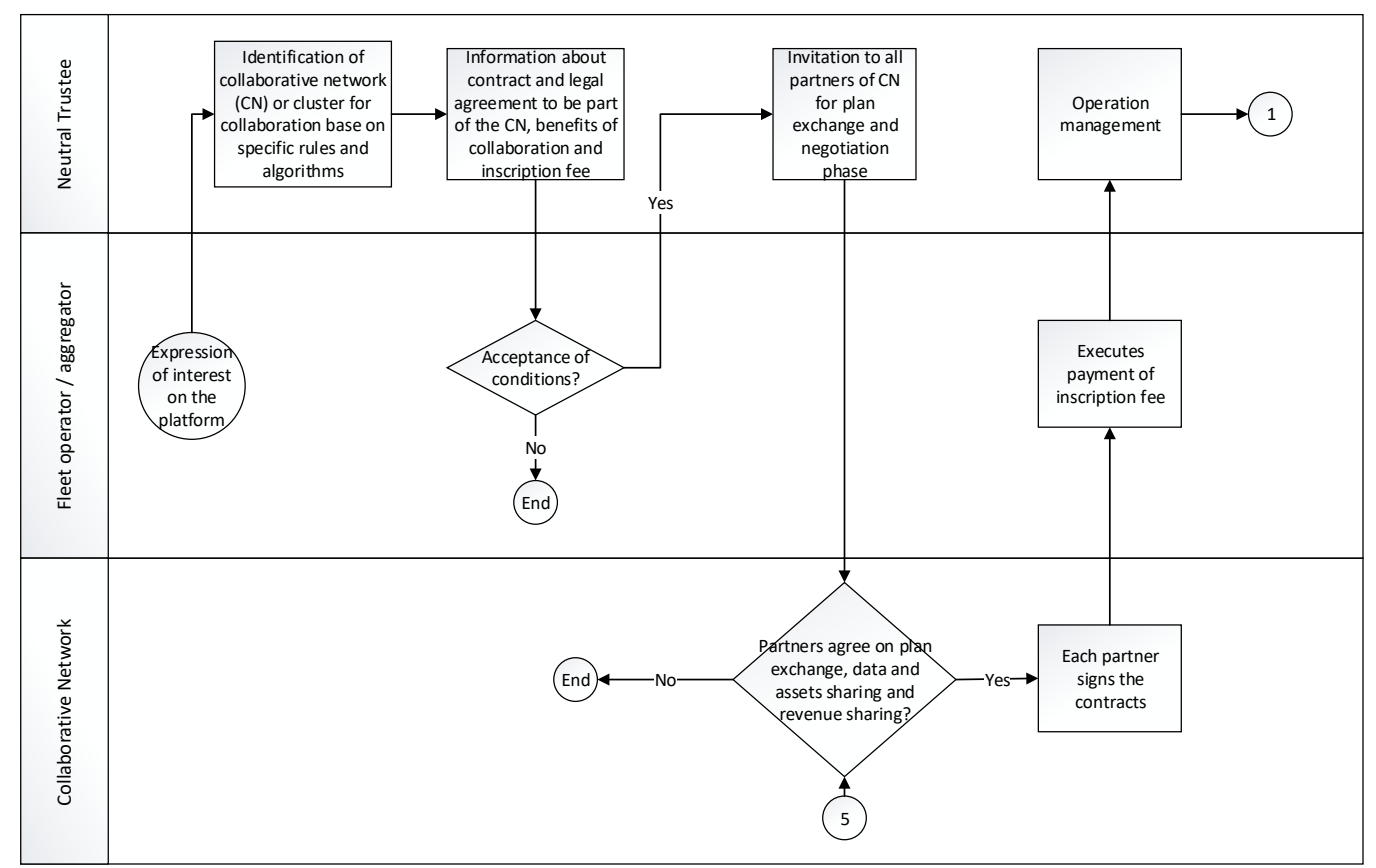

Figure 11. Workflow for proposed FSL business model-Collaboration initiation, Plan exchange, Negotiation and Revenue sharing.

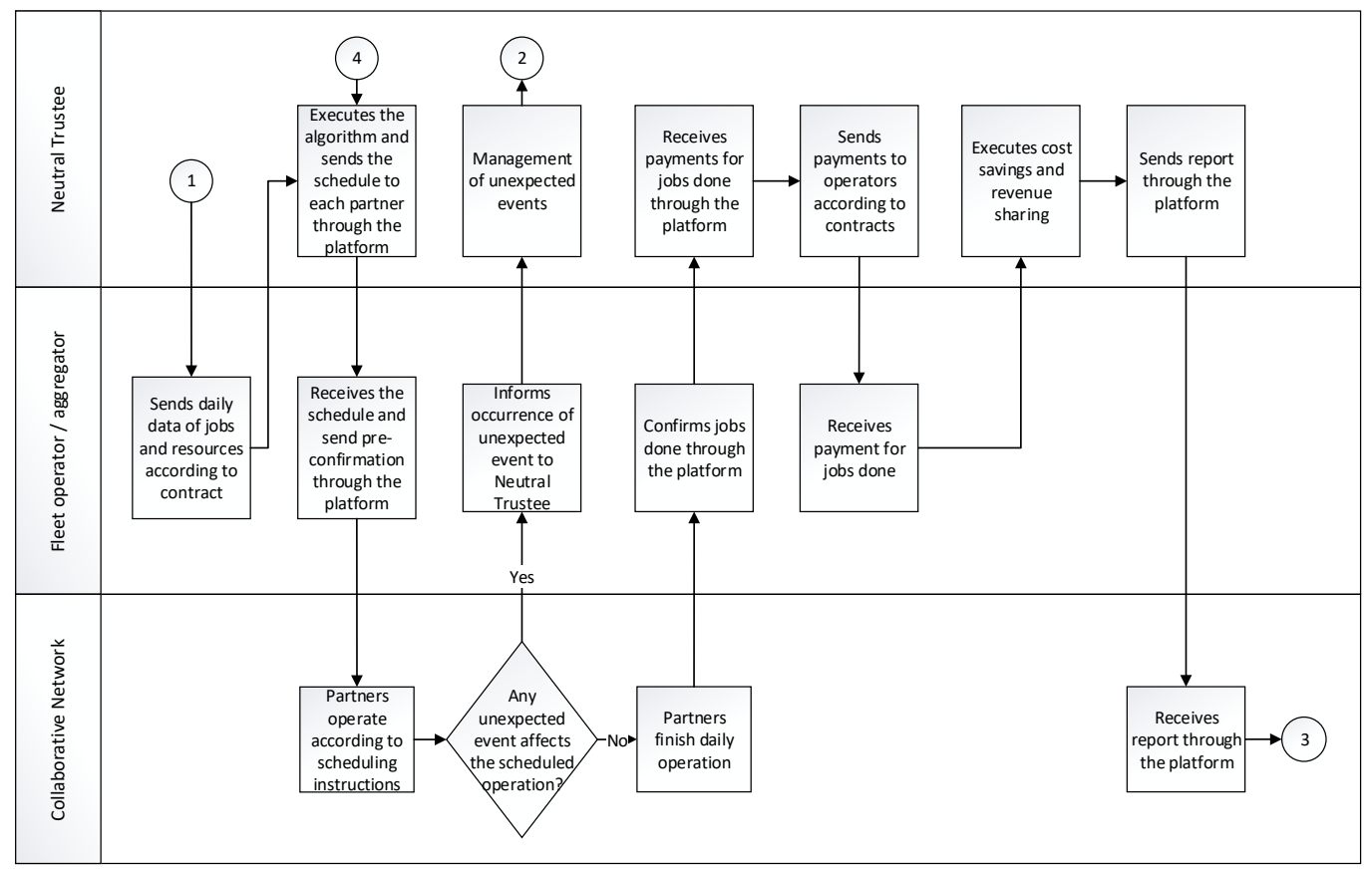

Figure 12. Workflow for proposed FSL business model—Collaboration operation. 


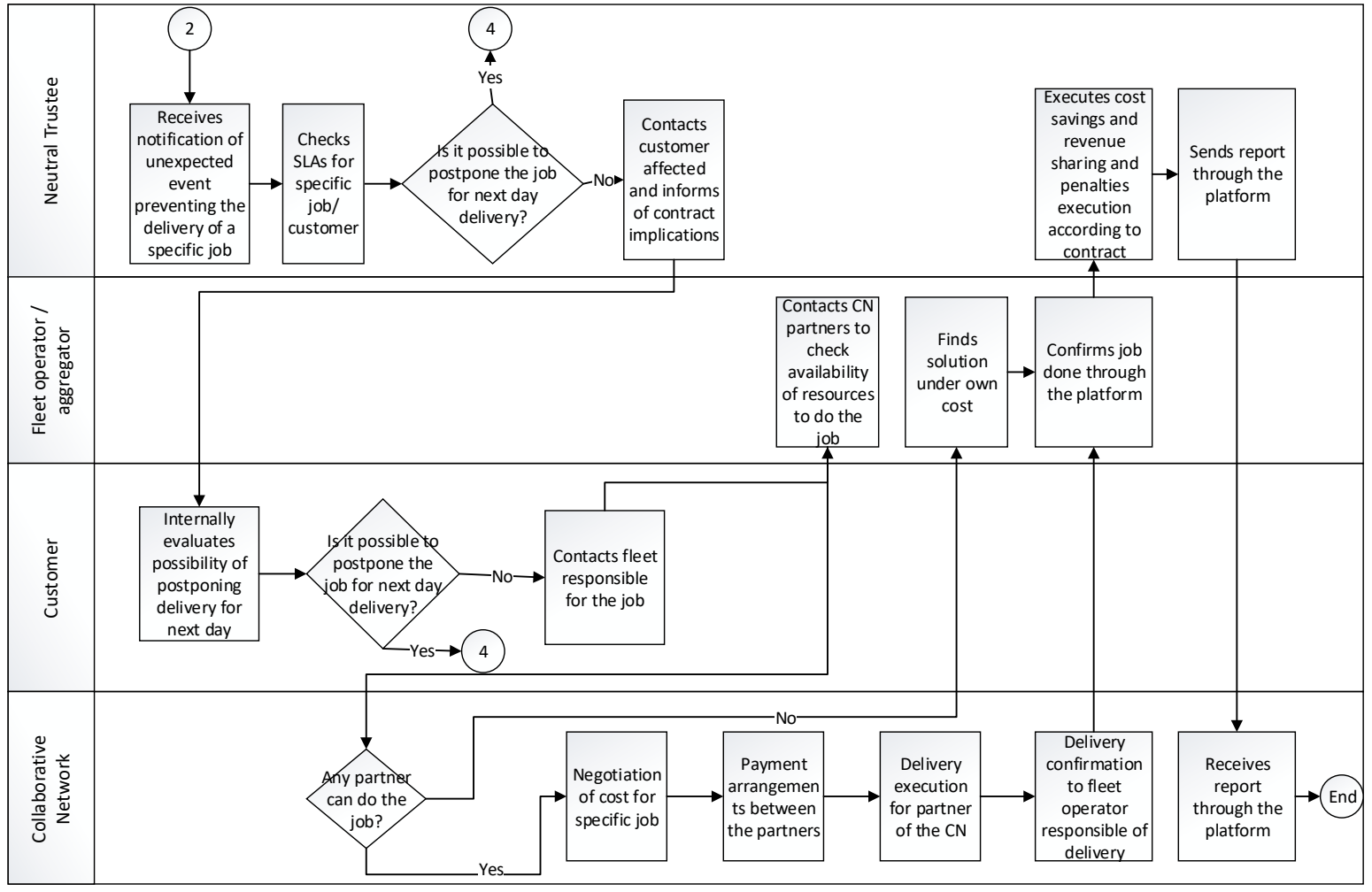

Figure 13. Workflow for proposed FSL business model-Management of unexpected events.

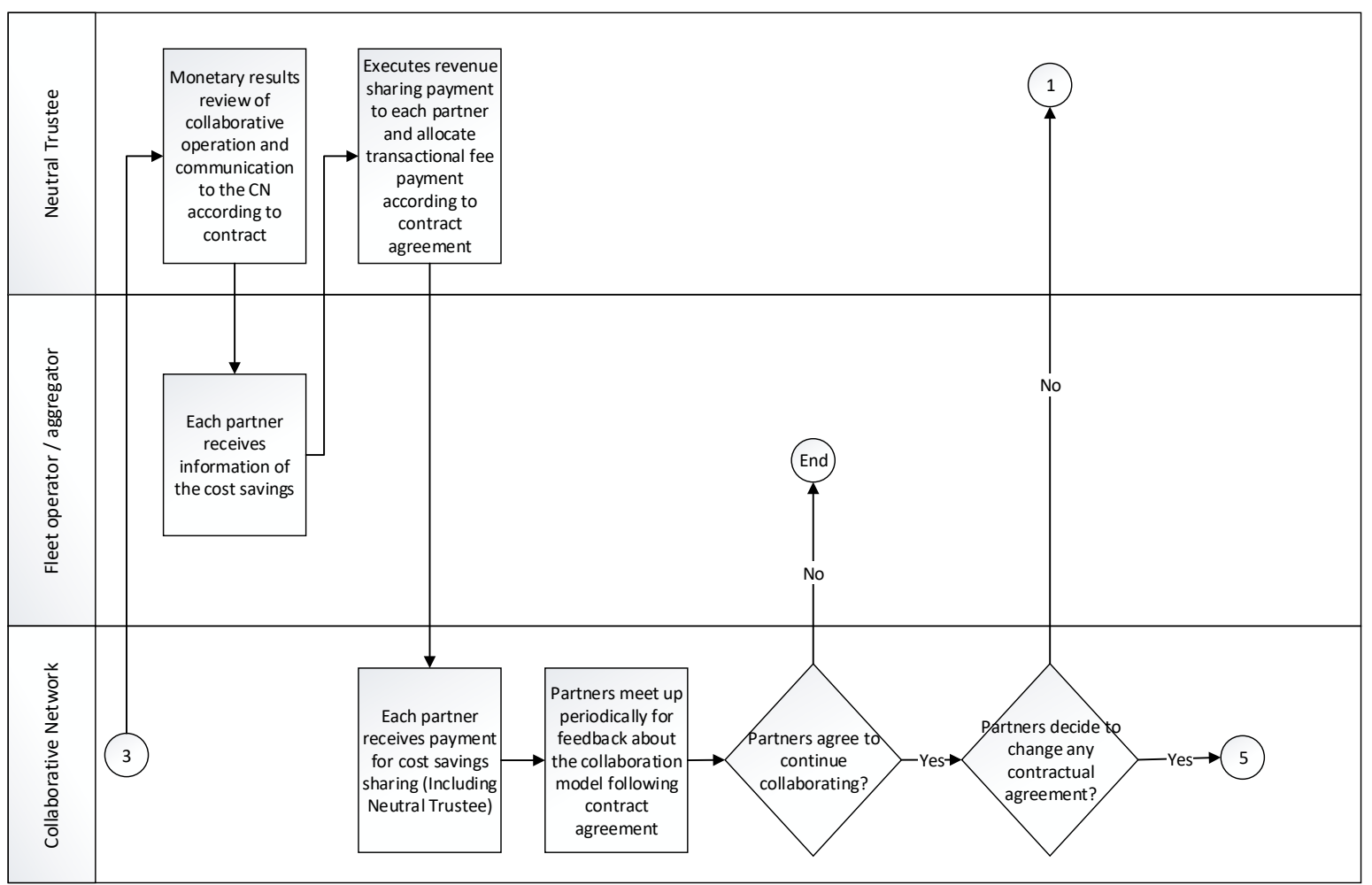

Figure 14. Workflow for proposed FSL business model—Results measure, Revenue sharing execution and Feedback. 


\section{Conclusions}

The proposed framework addresses some problematic areas in freight collaboration by defining the main components needed to manage the areas. The framework also seeks to standardize the building blocks to support the use of the framework as a tool to compare different business models and identify the best innovative components for the creation of improved business models. The instantiation of the case study addresses the key challenges the sector is facing, specifically trust, competition and revenue sharing. The instantiation identifies key components, forms and strategies of collaboration to support the freight industry and provides the basis for a mechanism for sharing resources and apportioning revenue fairly and equitably. The case study highlights the benefits fleets can gain by engaging with the FSL platform and proposes strategic, tactical and operational decisions for collaboration and subsequent workflows. This approach will enable the development of a standardised component-based system for collaboration in the freight industry.

The theoretical approach presented in this paper provides a basis to use action research to evaluate the freight collaboration business model. Future work will explore validating the functionality of the model in different case studies, starting with FSL. To achieve this, the required data and information is being collected through interviews and consultations within the sector. In parallel, the operational Decision Support System (DSS) that will support the validation of the current proposal is being developed.

Author Contributions: Conceptualization and analysis, A.V.; Methodology, A.V. and S.P.; Investigation, A.V.; Writing-Original Draft Preparation, A.V.; Writing-Review \& Editing, S.P. and D.P. All authors have read and approved the final version.

Acknowledgments: This research has been carried out in the framework of the Freight Share Lab (FSL) project partially funded by Innovate UK. We thank our colleagues from the F SL consortium: TrackM8 (formerly Route Monkey), DVV Media International, Transport Systems Catapult and Herriot Watt University, who provided insight and expertise that greatly assisted this research, although they may not agree with all of the interpretations and conclusions of this independently produced paper. Finally, we thank the anonymous reviewers for their constructive and valuable comments.

Conflicts of Interest: The authors declare no conflict of interest.

\section{References}

1. TRL. Freight Industry Collaboration Study. London. 2017. Available online: https://trl.co.uk/sites/default/ files/PPR\%20812\%20-\%20Freight\%20Collaboration\%20Study.pdf (accessed on 29 September 2018).

2. DfT. Domestic Road Freight Statistics United Kingdom 2016. 2017. Available online: https: //www.gov.uk/government/uploads/system/uploads/attachment_data/file/627597/domesticroad-freight-statistics-2016.pdf (accessed on 29 September 2018).

3. NexTrust. New Multi Supplier-Multi Retailer Platform: Biscuits Suppliers and Retailers are Setting Up a Collaboration for Sustainable Logistics. 2017. Available online: http:/ /nextrust-project.eu/downloads/ Press_Release_MRMS-Platform_EN_\%281\%29.pdf (accessed on 29 September 2018).

4. Krajewska, M.A.; Kopfer, H. Collaborating freight forwarding enterprises Request allocation and profit sharing. In Container Terminals and Cargo Systems: Design, Operations Management, and Logistics Control Issues; Springer: Berlin, Germany, 2007; pp. 365-381.

5. Cao, M.; Zhang, Q. Supply chain collaboration: Impact on collaborative advantage and firm performance. J. Oper. Manag. 2011, 29, 163-180. [CrossRef]

6. Liao, S.H.; Kuo, F.I. The study of relationships between the collaboration for supply chain, supply chain capabilities and firm performance: A case of the Taiwans TFT-LCD industry. Int. J. Prod. Econ. 2014, 156, 295-304. [CrossRef]

7. Alarcón, F. Desarrollo de una Arquitectura para la Definición del Proceso de Comprometer Pedidos en Contextos de Redes de Suministro Colaborativas. Aplicación a una Red Compuesta por Cadenas de Suministro en los Sectores Cerámico y del Mueble. Ph.D. Thesis, Universidad Politecnica de Valencia, Valencia, Spain, 2005. 
8. Schmoltzi, C.; Wallenburg, C.M. Operational Governance in Horizontal Cooperations of Logistics Service Providers: Performance Effects and the Moderating Role of Cooperation Complexity. J. Supply Chain Manag. 2012. [CrossRef]

9. Lozano, S.; Moreno, P.; Adenso-Díaz, B.; Algaba, E. Cooperative game theory approach to allocating benefits of horizontal cooperation. Eur. J. Oper. Res. 2013. [CrossRef]

10. Dahl, S.; Derigs, U. Cooperative planning in express carrier networks-An empirical study on the effectiveness of a real-time Decision Support System. Decis. Support Syst. 2011. [CrossRef]

11. Okdinawati, L.; Simatupang, T.M.; Sunitiyoso, Y. Modelling Collaborative Transportation Management: Current State and Opportunities for Future Research. J. Oper. Supply Chain Manag. 2015, 8, 96-119. [CrossRef]

12. Gonzalez-Feliu, J.; Morana, J. Collaborative Transportation Sharing: From Theory to Practice via a Case Study from France. Available online: https: / / www.google.com/url?sa=t\&rct=j\&q=\&esrc=s\&source=web\&cd=1\& $\mathrm{cad}=$ rja\&uact=8\&ved=2ahUKEwjo25Oo6t_dAhWCE4gKHfiXAI0QFjAAegQICRAC\&url=https\%3A\%2F\% 2Fhalshs.archives-ouvertes.fr\%2Fhalshs-00798319\%2Fdocument\&usg=AOvVaw3O7M4UX6eG67PvA1TssIr (accessed on 29 September 2018).

13. Audy, J.F.; Lehoux, N.; D’Amours, S.; Rönnqvist, M. A framework for an efficient implementation of logistics collaborations. Int. Trans. Oper. Res. 2012, 19, 633-657. [CrossRef]

14. FSL. Truck Empty-Running the Target of New Collaborative Research Initiative. 2018. Available online: https:/ / www.freightsharelab.com/freightsharelab2018/en/node/newsitem-truck-empty-running-thetarget-of-new-collaborative-research-initiative (accessed on 25 September 2018).

15. Sutherland, J. Collaborative Trasportation Management: A Solution to Current Transportation Crisis. Bethlehem. 2006. Available online: https://www.illinois-library.com/pdf/collaborative-transportationmanagement-a-2a0b7.pdf (accessed on 29 September 2018).

16. Osório, A.L.; Camarinha-Matos, L.M.; Afsarmanesh, H. Enterprise collaboration network for transport and logistics services. IFIP Adv. Inf. Commun. Technol. 2013, 408, 267-278. [CrossRef]

17. Gonzalez-Feliu, J.; Salanova, J.-M. Defining and Evaluating Collaborative Urban Freight Transportation Systems. Procedia Soc. Behav. Sci. 2012, 39, 172-183. [CrossRef]

18. Camarinha-Matos, L.M.; Afsarmanesh, H.; Ollus, M. Ecolead and CNO base concepts. In Methods and Tools for Collaborative Networked Organizations; Springer: Boston, MA, USA, 2008; pp. 3-32.

19. Camarinha-Matos, L.M.; Afsarmanesh, H. Collaborative networks: A new scientific discipline. J. Intell. Manuf. 2005, 16, 439-452. [CrossRef]

20. Peeta, S.; Hernandez, S. Modeling of Collaborative Less-Than Truckload Carrier Freight Networks. 2011. Available online: https://pdfs.semanticscholar.org/2d69/8203895c57b575ce3a17db1d969d7ba4455f.pdf (accessed on 29 September 2018).

21. Ribas Vila, I.; Companys Pascual, R. Estado del arte de la Planificación Colaborativa en la Cadena de Suministro: Contexto Determinista e Incierto. Available online: https://www.google.

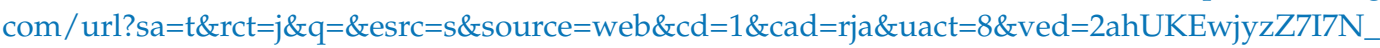
dAhUbA4gKHfh9A4sQFjAAegQICRAC\&url=https\%3A\%2F\%2Fupcommons.upc.edu\%2Fbitstream\% 2Fhandle\%2F2099\%2F3911\%2Fplanificacion_colaborativa.pdf\&usg=AOvVaw0_fGbnocFNfzEdDJJOZPhN (accessed on 29 September 2018).

22. Dudek, G. Supply Chain Management and Collaborative Planning; Springer: Berlin/Heidelberg, Germany, 2009.

23. Caballini, C.; Sacone, S.; Saeednia, M. Planning truck carriers operations in a cooperative environment. IFAC Proc. Vol. 2014, 47, 5121-5126. [CrossRef]

24. Cleophas, C.; Cottrill, C.; Ehmke, J.F.; Tierney, K. Collaborative urban transportation: Recent advances in theory and practice. Eur. J. Oper. Res. 2018. [CrossRef]

25. Verdonck, L.; Caris, A.N.; Ramaekers, K.; Janssens, G.K. Collaborative Logistics from the Perspective of Road Transportation Companies. Transp. Rev. 2013. [CrossRef]

26. Stadtler, H. A framework for collaborative planning and state-of-the-art. OR Spectr. 2009, 31, 5-30. [CrossRef]

27. Kilger, C.; Reuter, B.; Stadtler, H. Collaborative Planning. In Supply Chain Management and Advanced Planning; Springer: Berlin/Heidelberg, Germany, 2008; pp. 263-284.

28. Vargas, A.; Boza, A.; Cuenca, L.; Ortiz, A. Towards a framework for inter-enterprise architecture to boost collaborative networks. In On the Move to Meaningful Internet Systems: OTM 2013 Workshops; Lecture Notes in Computer Science; Springer: Berlin/Heidelberg, Germany, 2013; Volume 8186. [CrossRef] 
29. Petersen, K.J.; Ragatz, G.L.; Monczka, R.M. An examination of collaborative planning effectiveness and supply chain performance. J. Supply Chain Manag. 2005, 41, 14-25. [CrossRef]

30. Verheij, H.; Augenbroe, G. Collaborative planning of AEC projects and partnerships. Autom. Constr. 2006, 15, 428-437. [CrossRef]

31. Peeters, K.; Bogens, M.; Stumm, P. NexTrust Deliverable 1.1 Report-Results of Identification Phase. 2017. Available online: http:/ / nextrust-project.eu/downloads/D1.1_Identification_Phase.pdf (accessed on 29 September 2018).

32. Vargas, A.; Boza, A.; Patel, S.; Patel, D.; Cuenca, L.; Ortiz, A. Inter-enterprise architecture as a tool to empower decision-making in hierarchical collaborative production planning. Data Knowl. Eng. 2016, 105. [CrossRef]

33. Morana, J.; Gonzales-Feliu, J.; Semet, F. Urban consolidation and logistics pooling: Planning, management and scenario assessment issues. In Sustainable Urban Logistics: Concepts, Methods and Information Systems; Springer: Berlin/Heidelberg, Germany, 2014; pp. 187-210. [CrossRef]

34. Allen, J.; Bektas, T.; Cherrett, T.; Friday, A.; Mcleod, F.; Piecyk, M.; Piotrowska, M.; Austwick, M.Z. Enabling the Freight Traffic Controller for Collaborative Multi-Drop Urban Logistics: Practical and Theoretical Challenges. Transp. Res. Rec. J. Transp. Res. Board 2017, 2609, 77-84. [CrossRef]

35. Cruijssen, F.; Cools, M.; Dullaert, W. Horizontal cooperation in logistics: Opportunities and impediments. Transp. Res. Part E Logist. Transp. Rev. 2007. [CrossRef]

36. Verstrepen, S.; Cools, M.; Cruijssen, F.; Dullaert, W. A dynamic framework for managing horizontal cooperation in logistics. Int. J. Logist. Syst. Manag. 2009. [CrossRef]

37. Bloos, M.; Kopfer, H. On the Formation of Operational Transport Collaboration Systems. Dyn. Logist. 2011. [CrossRef]

38. Guajardo, M.; Rönnqvist, M. A review on cost allocation methods in collaborative transportation. Int. Trans. Oper. Res. 2016. [CrossRef]

39. Palhazi Cuervo, D.; Vanovermeire, C.; Sörensen, K. Determining collaborative profits in coalitions formed by two partners with varying characteristics. Transp. Res. Part C Emerg. Technol. 2016. [CrossRef]

40. Kimms, A.; Kozeletskyi, I. Core-based cost allocation in the cooperative traveling salesman problem. Eur. J. Oper. Res. 2016. [CrossRef]

41. Kimms, A.; Kozeletskyi, I. Shapley value-based cost allocation in the cooperative traveling salesman problem under rolling horizon planning. EURO J. Transp. Logist. 2016. [CrossRef]

42. Frisk, M.; Göthe-Lundgren, M.; Jörnsten, K.; Rönnqvist, M. Cost allocation in collaborative forest transportation. Eur. J. Oper. Res. 2010. [CrossRef]

43. Hezarkhani, B.; Slikker, M.; Van Woensel, T. A competitive solution for cooperative truckload delivery. OR Spectr. 2016. [CrossRef]

44. Dai, B.; Chen, H. Profit allocation mechanisms for carrier collaboration in pickup and delivery service. Comput. Ind. Eng. 2012. [CrossRef]

45. Montoya-Torres, J.R.; Muñoz-Villamizar, A.; Vega-Mejía, C.A. On the impact of collaborative strategies for goods delivery in city logistics. Prod. Plan. Control 2016. [CrossRef]

46. Ouhader, H.; El kyal, M. Combining Facility Location and Routing Decisions in Sustainable Urban Freight Distribution under Horizontal Collaboration: How Can Shippers Be Benefited? Math. Probl. Eng. 2017. [CrossRef]

47. Gansterer, M.; Hartl, R.F. Collaborative vehicle routing: A survey. Eur. J. Oper. Res. 2018. [CrossRef]

48. Vanovermeire, C.; Sörensen, K.; Van Breedam, A.; Vannieuwenhuyse, B.; Verstrepen, S. Horizontal logistics collaboration: Decreasing costs through flexibility and an adequate cost allocation strategy. Int. J. Logist. Res. Appl. 2014. [CrossRef]

49. Gansterer, M.; Hartl, R.F. Request evaluation strategies for carriers in auction-based collaborations. OR Spectr. 2016. [CrossRef]

50. Carbone, V.; Rouquet, A.; Roussat, C. The Rise of Crowd Logistics: A New Way to Co-Create Logistics Value. J. Bus. Logist. 2017. [CrossRef]

51. Buldeo Rai, H.; Verlinde, S.; Merckx, J.; Macharis, C. Crowd logistics: An opportunity for more sustainable urban freight transport? Eur. Transp. Res. Rev. 2017. [CrossRef]

52. Nguyen, N.; Nghiem, N.-V.-D.; Do, P.-T.; Le, K.-T.; Nguyen, M.-S.; Mukai, N. People and parcels sharing a taxi for Tokyo city. In Proceedings of the Sixth International Symposium on Information and Communication Technology, Hue City, Viet Nam, 3-4 December 2015. [CrossRef] 
53. Li, B.; Krushinsky, D.; Van Woensel, T.; Reijers, H.A. The Share-a-Ride problem with stochastic travel times and stochastic delivery locations. Transp. Res. Part C Emerg. Technol. 2016. [CrossRef]

54. Ronald, N.; Yang, J.; Thompson, R.G. Exploring Co-Modality Using On-Demand Transport Systems. Transp. Res. Procedia 2016. [CrossRef]

55. Linares, M.P.; Montero, L.; Barceló, J.; Carmona, C. A simulation framework for real-Time assessment of dynamic ride sharing demand responsive transportation models. In Proceedings of the 2016 Winter Simulation Conference (WSC), Washington, DC, USA, 11-14 December 2016. [CrossRef]

56. wbcsd. Road Freight Lab: Demonstrating the GHG Reduction Potential of Asset Sharing, Asset Optimisation and Other Measures. 2016. Available online: https://www.wbcsd.org/Clusters/Climate-Energy/ Resources/Demonstrating-GHG-reduction-potential-asset-sharing-asset-optimization-and-othermeasures (accessed on 29 September 2018).

57. wbscd. Road Freight Lab: A Low Carbon Freight Report under WBCSD's Low Carbon Technology Partnerships Initiative (LCTPi). 2017. Available online: Https://www.wbcsd.org/Clusters/ClimateEnergy / Road-Freight-Lab / Resources / A-Low-Carbon-Freight-report-under-WBCSDs-LCTPi (accessed on 29 September 2018).

58. Todeva, E.; Knoke, D. Strategic alliances and models of collaboration. Manag. Decis. 2005, 43, $123-148$. [CrossRef]

59. Bogens, M.; Verstrepen, S. $\mathrm{CO}_{3}$ Position Paper: Added Value of ICT on Logistics Horizontal Collaboration: Identifying the Need for an Integrated Approach. 2013. Available online: http://www.co3-project. eu/wo3/wp-content/uploads/2011/12/CO3-D-4-4-Added-value-of-ICT-in-Logistics.pdf (accessed on 29 September 2018).

60. Bogens, M.; Stumm, P. NexTrust Deliverable 2.1 Report-Network Identification. 2017. Available online: http://nextrust-project.eu/downloads/D2.1_Network_Identification_V7_\%281\%29.pdf (accessed on 29 September 2018).

61. NexTrust. Collaboration in Logistics Is Achieving Breakthrough. 2017. Available online: http:/ / nextrust-project.eu/downloads/Collaboration_in_logistics_is_achieving_breakthrough.pdf (accessed on 29 September 2018).

62. ENIDE. Clusters 2.0. Open Netw Hyper Connect Logist Clust Dissem Mater. 2017. Available online: http:/ / www.clusters20.eu/wp-content/uploads/2018/01/Clusters-2.0-Newsletter-1-v180109.01.pdf (accessed on 29 September 2018).

63. PTV. Modular Logistics Units in Shared Co-modal Networks. 2016. Available online: https:/ / cordis.europa. $\mathrm{eu} /$ docs / results/314/314468/ final1-modulushca-finalreport-sectiona.pdf (accessed on 29 September 2018).

64. Fabbe-Costes, N. Systèmes D'information Logistique et Transport. Available online: https: / / www.techniques-ingenieur.fr/base-documentaire/genie-industriel-th6/transport-et-logistique42123210/systeme-d-information-logistique-et-transport-ag8030/ (accessed on 29 September 2018).

65. Kale, R.; Evers, P.T.; Dresner, M.E. Analyzing private communities on Internet-based collaborative transportation networks. Transp. Res. Part E Logist. Transp. Rev. 2007, 43, 21-38. [CrossRef]

66. Jenks, C.; Jencks, C.; Navarrete, J.; Baker, T.; Delaney, E.; Hagood, M. Freight Data Sharing Guidebook. Washington. 2013. Available online: https://www.nap.edu/read/22569/chapter/1 (accessed on 29 September 2018).

67. Eckartz, S.M.; Hofman, W.J.; Van Veenstra, A.F. A Decision Model for Data Sharing. In Electronic Government, Proceedings of the International Conference on Electronic Government, Dublin, Ireland, 1-3 September 2014; Springer: Berlin/Heidelberg, Germany, 2014; Volume 8653, pp. 253-264.

68. Greening, P.; Piecyk, M.; Palmer, A.; McKinnon, A. An Assessment of the Potential for Demand-Side Fuel Savings in the Heavy Goods Vehicle (HGV) Sector. 2015. Available online: https:/ / www.theccc.org.uk/wp-content/uploads/2015/11/CfSRF-An-assessment-of-the-potential-fordemand-side-fuel-savings-in-the-HGV-sector.pdf (accessed on 29 September 2018).

69. Nadarajah, S.; Bookbinder, J.H. Less-Than-Truckload carrier collaboration problem: Modeling framework and solution approach. J. Heuristics 2013, 19, 917-942. [CrossRef]

70. Osterwalder, A. The Business Model Ontology-A Proposition in a Design Science Approach. Ph.D. Thesis, Université de Lausanne, Lausanne, Switzerland, 2004.

71. Osterwalder, A.; Pigneur, Y. Business Model Generation: A Handbook for Visionaries, Game Changers, and Challengers; John Wiley \& Sons, Inc.: Hoboken, NJ, USA, 2010. [CrossRef] 
72. Kaplan, R.; Norton, D. The Balanced Scorecard-Measures That Drive Performance. Harvard Bus. Rev. 1992, $70,71-79$.

73. ECR. 2degrees. Transp Collab Guid. 2015. Available online: https://www.2degreesnetwork.com/groups / 2degrees-community/resources/igd-guide-transport-collaboration/ (accessed on 4 April 2018).

74. Guinouet, A.; Jordans, M.; Cruijssen, F. CO 3 -Project. C CO 3 Case Study Retail Collab Fr. 2012. Available online: http:/ / www.co3-project.eu/wo3/wp-content/uploads/2011/12/20121128-Mars-CO3Case-Study.pdf (accessed on 4 April 2018).

75. Returnloads.net. 2018. Available online: https://www.returnloads.net/ (accessed on 4 April 2018).

76. DfT. Freight Carbon Review. Moving Britain Ahead. 2017. Available online: https://www.gov.uk/ government/uploads/system/uploads/attachment_data/file/590922/freight-carbon-review-2017.pdf (accessed on 29 September 2018).

77. Vargas, A.; Boza, A.; Patel, S.; Patel, D.; Cuenca, L.; Ortiz, A. Risk management in hierarchical production planning using inter-enterprise architecture. In Risks and Resilience of Collaborative Networks, Proceedings of the Working Conference on Virtual Enterprises, Albi, France, 5-7 October 2015; Springer: Cham, Switzerland, 2015; Volume 463. [CrossRef]

(C) 2018 by the authors. Licensee MDPI, Basel, Switzerland. This article is an open access article distributed under the terms and conditions of the Creative Commons Attribution (CC BY) license (http:/ / creativecommons.org/licenses/by/4.0/). 